January 2020

\title{
Margins: Estimating the Influence of the Big Three on Shareholder Proposals
}

Caleb Griffin

Belmont University

Author(s) ORCID Identifier:

0000-0002-9132-8428

\section{Recommended Citation}

Caleb Griffin, Margins: Estimating the Influence of the Big Three on Shareholder Proposals, 73 SMU L. REV. 409 (2020)

https://scholar.smu.edu/smulr/vol73/iss3/6

This Article is brought to you for free and open access by the Law Journals at SMU Scholar. It has been accepted for inclusion in SMU Law Review by an authorized administrator of SMU Scholar. For more information, please visit http://digitalrepository.smu.edu. 


\title{
MARgins: Estimating THE INFLUENCE OF THE BIG THREE ON Shareholder Proposals
}

\author{
Caleb N. Griffin*
}

\begin{abstract}
This Article contributes to the growing literature on the influence of index funds on corporate governance by providing new data on index funds' ownership, voting control, and impact on shareholder proposal outcomes. The Article first presents data on the firm ownership and voting control of the three largest index funds (the Big Three) at Fortune 250 companies. It finds that the Big Three combined are the largest shareholder in 96\% of Fortune 250 companies, that Vanguard and BlackRock combined (the Big Two) are the largest shareholder in $94.4 \%$ of such companies, and that Vanguard alone (the Big One) is the largest shareholder in $65.6 \%$ of such companies.

The Article next analyzes the power of the Big Three index funds to decide the outcome of shareholder proposals. It presents data on the voting margins for all shareholder proposals at Fortune 250 companies in calendar years 2018 and 2019. It then pairs the voting-margin data with the voting-control data to provide a market-wide picture of which shareholder proposals are likely within the Big Three's influence. The findings suggest that the Big Three already possess sufficient voting power to determine the outcome of a majority of shareholder proposals.

Additionally, the Article provides data on the Big Three's influence over specific categories of shareholder proposals. It finds that the Big Three have the power to determine approximately $50 \%$ of the environmental and social proposals (with low error rates) and approximately $65 \%$ of governance proposals (with somewhat higher error rates). In light of these findings, the Article explores the profound implications of this proxy voting power and proposes methods for investors to reclaim their autonomy.
\end{abstract}

\section{TABLE OF CONTENTS}

I. INTRODUCTION ............................. 410

II. THE RISE OF THE BIG THREE ................ 412

III. DATA ON THE BIG THREE'S INFLUENCE .......... 417

IV. DATA ON MARGINS FOR 2018-2019 VOTES ......... 420

A. Environmental Proposals .................. 422

* Assistant Professor of Law, Belmont University College of Law. 
B. Social Proposals ......................... 424

C. Governance Proposals ....................... 431

D. All Shareholder Proposals................. 438

V. IMPLICATIONS .............................. 438

VI. CONCLUSION ............................. 442

\section{INTRODUCTION}

I

NDEXED investing has exploded in popularity over the past two decades. In August 2019, U.S. equity index fund assets officially surpassed their actively managed counterparts for the first time, reaching $\$ 4.27$ trillion in total assets under management. ${ }^{1}$ This achievement, and the underlying growth in indexed investing, represents one of the most important power transfers in the history of capital markets.

Just three index fund providers-Vanguard, BlackRock, and State Street (collectively, the Big Three)—control the vast majority of indexed capital. Because of the legal structure of index funds, the Big Three have the right to vote the shares purchased with their investors' money, subject only to minimal constraints. ${ }^{2}$ Thus, the Big Three are not just managers of an enormous amount of capital but are stewards responsible for making pivotal decisions for the companies in which that capital is invested. Given their voting influence, the concentration of power in the hands of the Big Three has become a source of concern for academics and policymakers. In particular, experts fear that these agents have or will soon obtain undue power over corporate governance ${ }^{3}$ and that they may have insufficient or improper incentives for promoting good governance practices. ${ }^{4}$

1. Dawn Lim, Index Funds Are the New Kings of Wall Street, Wall St. J. (Sept. 18, 2019), https://www.wsj.com/articles/index-funds-are-the-new-kings-of-wall-street-1156879 9004 [https://perma.cc/9KPD-U345].

2. See generally Disclosure of Proxy Voting Policies and Proxy Voting Records by Registered Management Investment Companies, 68 Fed. Reg. 6564 (Feb. 7, 2003) [hereinafter Disclosure of Proxy Voting].

3. See, e.g., Jan Fichtner et al., Hidden Power of the Big Three? Passive Index Funds, Re-Concentration of Corporate Ownership, and New Financial Risk, 19 Bus. \& Pol. 298, 316-17 (2017) (finding that the Big Three's rise in power represents unprecedented levels of concentrated corporate ownership); Eric A. Posner et al., A Proposal to Limit the AntiCompetitive Power of Institutional Investors, 81 AntiTRust L.J. 669, 676 (2017) (warning of anti-competitive effects from passive ownership); John C. Coates IV, The Future of Corporate Governance Part I: The Problem of Twelve 2-3 (Harvard John M. Olin Discussion Paper Series, Paper No. 1001, 2019), http://www.law.harvard.edu/programs/olin_center/papers/pdf/Coates_1001.pdf [https://perma.cc/PM5F-PQDS] (warning of the threat of concentrated decision-making associated with the rise of passive investment).

4. See, e.g., Michal Barzuza et al., Shareholder Value(s): Index Fund Activism and the New Millennial Corporate Governance, 93 S. CAL. L. REv. (forthcoming 2020) (describing index funds as having improper incentives to use their power to attract new clients rather than to promote the interests of existing clients); Lucian Bebchuk \& Scott Hirst, Index Funds and the Future of Corporate Governance: Theory, Evidence, and Policy, 119 Colum. L. REv. 2029, 2050-72 (2019) (arguing that index funds possess insufficient incentives to engage in beneficial corporate governance practices and that they have improper incentives to be overly deferential to management); Edward B. Rock, The Logic and (Uncer- 
One realm of index funds' voting influence that may be particularly salient for shareholders is shareholder proposals. While other ballot items tend to be routine, and therefore relatively uncontroversial, shareholder proposals tend to be far more divisive. Moreover, these proposals often touch on quasi-political topics such as climate change, gender pay disparities, diversity, corporate lobbying, and pollution. It is unlikely that the large and diverse pool of individuals who constitute the Big Three's investors are of one mind about such topics. Given the controversial nature and important role of such proposals in the shareholder franchise, this Article asks the question: what impact do the Big Three have on shareholder proposals?

To begin to answer this question, this Article examines the influence of the largest index fund managers on shareholder proposals at the 250 largest publicly traded companies in the United States. This Article demonstrates that the Big Three combined serve as the largest shareholder at $96 \%$ of the largest 250 publicly traded companies in the United States, that Vanguard and BlackRock combined (the Big Two) serve as the largest shareholder at $94.4 \%$ of such companies, and that Vanguard alone (the Big One) is the single largest shareholder at $65.6 \%$ of such companies. ${ }^{5}$ Additionally, it finds that, on average, the Big Three control $20.1 \%$ of shares at these companies, and it estimates that the Big Three cast a combined $25 \%$ of the proxy votes, on average, at these companies. ${ }^{6}$ It further estimates Vanguard's average voting influence as $10.6 \%$, BlackRock's as $9.0 \%$, and State Street's as $4.4 \% .7$

Utilizing this data on the Big Three's sphere of influence at the 250 largest companies, this Article examines the margins of the 511 shareholder proposals at issue at these companies in calendar years 2018 and $2019 .{ }^{8}$ It finds that nearly one-fifth of such proposals have margins of less than $10.6 \%$, potentially placing these proposals within Vanguard's sole decision-making power. It further finds that over four-tenths of such proposals have margins of less than $19.6 \%$, meaning that these proposals may be determined by just Vanguard and BlackRock, which tend to vote near-identically in opposition to the vast majority of shareholder proposals. Finally, over one-half of such proposals are decided by margins of less than $25 \%$, making them vulnerable to the combined actions of the Big Three. Overall, the data suggest that individually, the Big Three already have the potential to determine a significant proportion of proxy votes, and that combined, they possess the power to decide the outcome of a majority of shareholder proposals.

tain) Significance of Institutional Shareholder Activism, 79 GEO. L.J. 445, 473-74 (1991) (arguing that index fund managers have few incentives to act in the best interests of their principals with regard to corporate governance).

5. See infra Table 2.

6. See infra Table 1.

7. $I d$.

8. Proxy Monitor, https://www.proxymonitor.org [https://perma.cc/V3RR-XXFL] (database tracking shareholder proposals for the Fortune 250 companies). 
Nearly all shareholder proposals are "precatory," or nonbinding. ${ }^{9}$ Such proposals derive their power from the fact that directors have fiduciary duties to act in the best interests of the corporation and its shareholders. When shareholders collectively express a strong preference for a given action or policy, this constitutes strong evidence of what they consider to be their best interests. As such, this Article uses majority support as its benchmark for assessing the margins on shareholder proposals. In practice, even if a shareholder proposal fails to win majority support, significant minority support often causes the board to implement the proposal despite the failed vote. ${ }^{10}$ Because of this fact, support for shareholder proposals from the Big Three becomes even more important, given that the trio may constitute a "significant minority" of shares without any additional support. This Article may thus understate the impact of the Big Three's voting behavior in terms of whether their behavior results in implementation of a given proposal.

This Article proceeds as follows: Part II briefly explores the rise of the Big Three's power and the ways that the Big Three influence corporate decision-making. Part III provides data on the Big Three's influence at the 250 largest publicly traded companies in the U.S. (the Fortune 250), including the Big Three's voting influence and the percentage of companies at which the Big Three serve as the single largest shareholder, individually or collectively. Part IV provides data on the margins for all shareholder proposals at Fortune 250 companies for calendar years 2018 and 2019. Part V argues that the Big Three's current power to influence shareholder proposals underscores the need for action to constrain index funds' power and to align that power with investors' interests and preferences. Part VI sets forth this Article's conclusions.

\section{THE RISE OF THE BIG THREE}

Passive investment funds feature as a defining characteristic the goal of replicating the performance of an existing market index ${ }^{11}$ instead of attempting to select certain stocks believed to outperform the market (an orientation that characterizes "active funds"). ${ }^{12}$ Passive investment funds include both index funds, which trade once daily after the close of markets, ${ }^{13}$ and exchange-traded funds (ETFs), which trade continuously

9. Keith F. Higgins, Director, Division of Corporation Finance, U.S. Sec. \& Exch. Comm'n, Rule 14a-8: Conflicting Proposals, Conflicting Views (Feb. 10, 2015), www.sec. gov/news/speech/rule-14a-8-conflicting-proposals-conflicting-views.html [https://perma.cc/ AD9R-GXBE].

10. See Virginia Harper Ho, Nonfinancial Risk Disclosure and the Costs of Private Ordering, 55 Am. Bus. L.J. 407, 420-22 (2018).

11. Dorothy S. Lund, The Case Against Passive Shareholder Voting, 43 J. Corp. L. 493, 506 (2018).

12. Jeffrey M. Colon, The Great ETF Tax Swindle: The Taxation of In-Kind Redemptions, 122 Penn St. L. Rev. 1, 9 (2017).

13. William A. Birdthistle, The Fortunes and Foibles of Exchange-Traded Funds: A Positive Market Response to the Problems of Mutual Funds, 33 Del. J. Corp. L. 69, 72 (2008). 
throughout the day. ${ }^{14}$ Although the difference in trading behavior has important effects in some contexts, for the purposes of this Article index funds and ETFs will be referred to collectively by the terms "passive funds" and "index funds."

When index funds first emerged in the mid-1970s, Wall Street largely rejected the notion that the market as a whole could outperform selections of promising stocks handpicked by experts. ${ }^{15}$ The Leuthold Group, a research firm, circulated posters with the slogans "INDEX FUNDS ARE UNAMERICAN!" and "Help Stamp Out Index Funds."16 Other critics referred to index funds as "a sure path to mediocrity" and "Bogle's Folly."17

However, the passive nature of passive investing has a key advantage in that it entails relatively minimal costs in the form of research, employee salaries, and stock selection. Index funds can pass on these cost savings to consumers in the form of low fees. ${ }^{18}$ These low fees--in combination with the inability of most active fund managers to consistently beat the market--has meant that passive funds have generally outperformed their actively managed counterparts. ${ }^{19}$ Indeed, just $23 \%$ of active funds surpassed their passive rivals over the ten-year period from June 2009 to June 2019. ${ }^{20}$

Over time, the financial success of index funds has drawn attention from commentators, financial advisors, academics, and ultimately, consumers, fueling the growth of these funds. That growth has been dramatic: index funds controlled just $4 \%$ of the equity mutual fund market in

14. Id.

15. Ben Steverman, The Index Fund Turns 40-And Gets Its Revenge, NASDAQ (Sept. 1, 2016), https://www.nasdaq.com/article/the-index-fund-turns-40-and-gets-its-re venge-cm673349 [https://perma.cc/H5AH-HMAF].

16. Id.

17. Jack Bogle: The Man Who Pioneered Index Investing, BBC News (Jan. 17, 2019), https://www.bbc.com/news/business-46906246 [https://perma.cc/UD3L-2RFW].

18. The asset-weighted average expense ratio for active mutual funds was $0.67 \%$ in 2018 compared with $0.15 \%$ for passive mutual funds. Morningstar, Annual U.S. Fund FEe STUDY 1 (2018), https://www.morningstar.com/lp/annual-us-fund-fee-study [https:// perma.cc/WLH7-YLG5]. But see Ian Ayres \& Quinn Curtis, Protecting Consumer Investors by Facilitating "Improved Performance" Competition, 2015 U. ILl. L. Rev. 1, 2-3 (2015) (noting that some index funds charge supracompetitive fees for their products).

19. Martin J. Gruber, Another Puzzle: The Growth in Actively Managed Mutual Funds, 52 J. FIN. 783, 787 (1996) (finding that actively managed funds underperformed related indices by sixty-five basis points); Russ Wermers, Mutual Fund Performance: An Empirical Decomposition into Stock-Picking Talent, Style, Transactions Costs, and Expenses, 55 J. FIN. 1655, 1690 (2000) (finding that actively managed funds underperform indices by 1\%); Aye M. Soe et AL., SPIVA U.S. Year-End 2018 SCORECARD, S\&P Dow JONES INDICES 1 (2019), https://www.spglobal.com/_assets/documents/corporate/us-spivareport-11-march-2019.pdf [https://perma.cc/9LF7-2FDY] (finding that the S\&P 500 index outperforms active managers for the ninth consecutive year).

20. Ben Johnson, Active Funds vs. Passive Funds: Which Fund Types Had Increased Success Rates?, Morningstar (Sept. 20, 2019), https://www.morningstar.com/insights/ 2019/09/20/active-vs-passive [https://perma.cc/4Q3Z-DKPH]. 
$1995,{ }^{21}$ but they controlled $34 \%$ in $2015^{22}$ and over $50 \%$ in $2019 .{ }^{23}$ Over the past decade, average inflows to index funds were eighteen times larger than the inflows to actively managed funds. ${ }^{24}$ Index funds now own approximately one-fifth of Standard and Poor's index of the 500 largest publicly-traded companies in the U.S. (S\&P 500), and they cast more than one-fourth of the votes at S\&P 500 companies. ${ }^{25}$

The growth of index investing has been not only incredibly rapid but also highly concentrated. The bulk of index fund capital is in the hands of the Big Three triopoly of Vanguard, BlackRock, and State Street. The Big Three together hold $81 \%$ of index fund assets. ${ }^{26}$ Competitors struggle to compete against these behemoths, given their extraordinary economies of scale that facilitate low fees and enable the funds to undercut a competitor's prices or mimic competitors' innovative products. ${ }^{27}$ Given these facts, the dominance of the Big Three is unlikely to subside. ${ }^{28}$

The Big Three's extreme and concentrated growth entails a number of important consequences for financial markets and the overall economy. In the realm of corporate governance, one feature is key: the ability of these funds to vote on behalf of their investors. The Big Three have not only a legal right to vote shares associated with their voluminous holdings ${ }^{29}$ but also arguably a fiduciary duty to do so. ${ }^{30}$ As such, these three index fund managers have developed infrastructure to engage in voting and other stewardship activities. These stewardship activities are generally performed by small teams of index fund employees, known as stewardship teams, which are charged with the responsibility of undertaking stewardship activities on behalf of the index fund. ${ }^{31}$

21. Lucian Bebchuk \& Scott Hirst, The Specter of the Giant Three, 99 B.U. L. REv. $721,727-28$ (2019).

22. $I d$.

23. Lim, supra note 1.

24. Bebchuk \& Hirst, supra note 21 , at $727-28$.

25. Id.

26. John C. Bogle, Bogle Sounds a Warning on Index Funds, Wall St. J. (Nov. 29, 2018), https://www.wsj.com/articles/bogle-sounds-a-warning-on-index-funds-1543504551 [https://perma.cc/YUE8-MT5B].

27. Coates, supra note 3 , at 13.

28. Id.

29. Bebchuk \& Hirst, supra note 21 , at $727-28$.

30. Interpretive Bulletin on Exercise of Shareholder Rights and Written Statements of Investment Policy, 29 C.F.R. $§ 2509.2016-01$ (2019) ("The fiduciary act of managing plan assets that are shares of corporate stock includes the voting of proxies appurtenant to those shares of stock.").While this technically applies only to securities held in employee benefit plan investment portfolios, it has affected proxy voting policy in other contexts as well. See Jill E. Fisch, The Uncertain Stewardship Potential of Index Funds, in Global Shareholder Stewardship: Complexities, Challenges and Possibilities 106 (Dionysia Katelouzou \& Dan W. Puchniak eds., Cambridge Univ. Press forthcoming) ("U.S. regulators have not adopted a formal requirement of investor stewardship. Certain components of what might be deemed a stewardship function are implicit, however, in other legal requirements that apply to institutional investors.").

31. BlackRock Investment Stewardship, BLAckRock 19 (2020), https://www.black rock.com/corporate/literature/publication/blk-profile-of-blackrock-investment-stewardship-team-work.pdf [https://perma.cc/JBD6-43HZ] (describing the activities of the BlackRock's stewardship team, including performing "approximately 2,500 engagements 
The activities of stewardship teams are tripartite in form. First, stewardship teams engage in priority-setting activities. ${ }^{32}$ Priority setting by itself can influence management to act preemptively in line with the stewardship teams' priorities. ${ }^{33}$ Such priority setting can encourage management to act preemptively, effectively sidestepping the need for public conflict in the proxy voting arena.

Second, stewardship teams engage in direct communications with management at thousands of companies annually, whether through letters, over the phone, or via in-person discussions. ${ }^{34}$ In these communications, referred to as engagements, stewardship teams encourage management to adopt or abandon particular behaviors or traits. ${ }^{35}$ Engagements occur at a sizable number of companies each year: Vanguard engaged with 868 companies in 2018, representing 59\% of its assets under management; ${ }^{36}$ BlackRock engaged with nearly 1,500 companies in 2018, representing $50.4 \%$ of its assets under management; ${ }^{37}$ and State Street engaged with 1,533 companies, representing $70 \%$ of the firm's assets under management in equities. ${ }^{38}$ Because of their substantial holdings and corresponding voting influence, the Big Three have the power to sway management in their preferred direction through these conversations without the need to resort to proxy voting.

annually, and undertak[ing] this activity on behalf of clients as a fiduciary regardless of investment vehicle or strategy type," and exercising "BlackRock's voting rights consistent with our firm's published voting guidelines"); VANGUARD, InVESTMENT STEWARDShIP 2019 ANNUAL REPORT 5 (2019), https://about.vanguard.com/investment-stewardship/perspectives-and-commentary/2019_investment_stewardship_annual_report.pdf [https:// perma.cc/233U-EF7W] [hereinafter VANGUARD 2019 InVESTMENT STEWARDSHIP REPORT] ("Our team represents Vanguard fund shareholders' interests through industry advocacy, company engagement, and proxy voting."); State Street Global Advisors, StewardSHIP REPORT 2018-19, at 22 (2019), https://www.ssga.com/investment-topics/environmental-social- governance/2019/09/annual-asset-stewardship-report-2018.pdf [https://perma.cc/ 735W-XL64] [hereinafter State Street 2019 Investment Stewardship Report] (“All voting and engagement activities are centralized within our Stewardship Team, irrespective of investment strategy or geographic region."); see also Lucian A. Bebchuk et al., The Agency Problems of Institutional Investors, 31 J. Econ. Pers. 89, 95 (2017) ("[T] he voting and stewardship decisions of mutual fund families are commonly concentrated in a single corporate governance department or proxy voting department of the investment manager . . . ."); Leo E. Strine, Jr., Who Bleeds When the Wolves Bite?: A Flesh-and-Blood Perspective on Hedge Fund Activism and Our Strange Corporate Governance System, 126 YALE L.J. 1870, 1915 (2017) ("[T]he fund family will, at best, establish a centralized voting unit comprised of comparatively less expensive employees, who will develop voting policies and make sure government mandates for voting are satisfied."). at 22 .

32. See, e.g., State Street 2019 Investment Stewardship Report, supra note 31,

33. Coates, supra note 3 , at 16.

34. Id.

35. Id.

36. Vanguard 2019 Investment Stewardship Report, supra note 31, at 8.

37. BlackRock, BlackRock 2019 Investment Stewardship Annual Report 4 (2019), https://www.blackrock.com/corporate/literature/publication/blk-annual-steward ship-report-2019.pdf [https://perma.cc/4EXX-PSPC] [hereinafter BLACKRock 2019 INVESTMENT STEWARDSHIP REPORT].

38. State Street 2019 Investment Stewardship Report, supra note 31, at 13. 
Third, stewardship teams are responsible for casting votes in shareholder elections. The law vests index funds with the legal authority and responsibility to engage in the proxy voting process in a manner consistent with the best interests of their investors. ${ }^{39}$ Although not explicitly required by law, index funds have acted as if they are required to vote substantially all of the shares under their control since 2003, when the Securities and Exchange Commission (SEC) issued guidance on the nature of their voting obligations. ${ }^{40}$ Given the expansive nature of index fund holdings, stewardship teams at the Big Three consider a great number of ballot items each year: Vanguard voted on nearly 170,000 individual proposals in the 2019 proxy year, ${ }^{41}$ BlackRock voted on just over 155,000 ballot items, ${ }^{42}$ and State Street voted on roughly 160,000 topics. ${ }^{43}$ As outlined below, the Big Three's proxy voting power gives them substantial influence over American corporate governance, given the large size of their holdings and the relatively narrow margins on many ballot items.

Even where the Big Three's votes are not sufficient to determine the outcome of the proxy vote outright, their votes may still influence corporate policies and procedures. First, for the reasons discussed above, even substantial minority support for a shareholder proposal may prompt the board to act on the issue in question. ${ }^{44}$ Second, rates of support also determine whether or not a given proposal may be resubmitted for consideration at a subsequent shareholder meeting. Under current rules, a company may exclude a shareholder proposal that "deals with substantially the same subject matter as another proposal or proposals that has or have been previously included in the company's proxy materials within the preceding 5 calendar years" if the matter was voted on at least once in the last three calendar years and received less than $3 \%$ of the vote if previously voted on once, $6 \%$ of the vote if previously voted on twice, or $10 \%$ of the vote if previously voted on three or more times. ${ }^{45}$ The SEC has proposed changes to these thresholds, under which a proposal could be excluded if the most recent vote occurred within the preceding three calendar years and did not receive at least $5 \%$ of the votes cast if previously voted on once, $15 \%$ of the votes cast if previously voted on twice, and $25 \%$ of the votes cast if previously voted on three or more times. ${ }^{46}$ Under either rule, the Big Three's control of a substantial proportion of votes cast means that the trio has the power to determine whether or not a proposal may be reconsidered in future years.

39. See generally Disclosure of Proxy Voting, supra note 2.

40. Jill Fisch et al., The New Titans of Wall Street: A Theoretical Framework for Passive Investors, 168 U. PA. L. REV. 17, 44 (2019).

41. Vanguard 2019 InVESTMEnt Stewardship Report, supra note 31, at 7.

42. BlackRock 2019 Investment Stewardship Report, supra note 37, at 4.

43. State Street 2019 Investment Stewardship Report, supra note 31, at 28.

44. Ho, supra note 10 , at 420-22.

45. 17 C.F.R. $\S 240.14 a-8(i)(12)$ (2020).

46. Procedural Requirements and Resubmission Thresholds under Exchange Act Rule 14a-8, 84 Fed. Reg. 66458 (proposed Dec. 4, 2019). 
Collectively, these three forms of stewardship give the Big Three unprecedented influence over public companies. Although all are key pathways by which these funds exert their influence, this Article focuses on the formal proxy voting process. The reasons for this are twofold: First, the proxy voting process is, despite considerable room for improvement, the most transparent of the three channels of influence. The thought processes and internal decision-making that occur when executives react to the stated priorities of the Big Three are naturally opaque, and the contents of the Big Three's informal engagements with executives at various companies are generally kept from the public eye. Thus, studying their proxy voting behavior offers us a clear picture of at least one facet of the Big Three's influence. Second, and more fundamentally, the proxy voting process is the driver of index funds' power in other areas. The Big Three's priority-setting activities and engagements are successful in large part because the Big Three possess significant voting power. Without such voting power, management could afford to ignore the Big Three's priorities and requests for action. With that in mind, this Article assesses the current power of index funds to shape corporate behavior along two axes. First, it considers the size of index funds' holdings and their corresponding voting power. Second, it considers the margins for shareholder proposals at the largest publicly traded companies. It compares these two figures to determine the potential extent of index fund power over proxy votes and, relatedly, whether the implicit threat of an antagonistic proxy vote is likely to influence management to act preemptively or responsively to engagement efforts by the Big Three.

\section{DATA ON THE BIG THREE'S INFLUENCE}

One dimension of the Big Three's influence over corporate governance is its ownership of a significant proportion of shares of the largest publicly traded companies in the United States. Prior research has established that the Big Three combined own an average of $20.5 \%$ of outstanding shares for S\&P 500 companies, with Vanguard owning 8.8\%, BlackRock owning $7.1 \%$, and State Street owning $4.6 \%$ of such shares. ${ }^{47}$ Similarly, previous research suggested that the Big Three combined own an average of $16.5 \%$ of outstanding shares for Russell 3000 companies, with Vanguard owning $6.6 \%$, BlackRock owning $7.3 \%$, and State Street owning $2.6 \%$ of such shares. ${ }^{48}$ This Article provides new data on the Big Three's ownership of the 250 largest publicly traded companies in the United States, and it finds that the combined mean ownership stake of the Big Three is $20.1 \%$, with Vanguard owning $8.4 \%$, BlackRock owning $7.3 \%$, and State Street owning $4.4 \%$ of such shares, figures consistent with prior findings.

47. Bebchuk \& Hirst, supra note 21 , at 736 ; see also David McLaughlin \& Annie Massa, The Hidden Dangers of the Great Index Fund Takeover, Bloomberg (Jan. 9, 2020), https://www.bloomberg.com/news/features/2020-01-09/the-hidden-dangers-of-the-great-index-fund-takeover [https://perma.cc/67Q6-C75R] (finding that the Big Three own $22 \%$ of the shares of the typical S\&P 500 company).

48. Bebchuk \& Hirst, supra note 21, at 736 . 


\section{Table 1: Big Three Ownership Shares at LARGEST 250 COMPANIES}

This Table reports the mean and median ownership rates ${ }^{49}$ for the Big Three individually and combined at the largest 250 publicly traded companies $^{50}$ in the United States. It also provides an estimate of the mean and median percentage of votes cast by each index fund company.

\begin{tabular}{|c|c|c|c|c|}
\hline Category & Vanguard & BlackRock & $\begin{array}{c}\text { State } \\
\text { Street }\end{array}$ & Combined \\
\hline $\begin{array}{c}\text { Mean Percentage of } \\
\text { Outstanding Shares }\end{array}$ & $8.4 \%$ & $7.3 \%$ & $4.4 \%$ & $20.1 \%$ \\
\hline $\begin{array}{c}\text { Median Percentage of } \\
\text { Outstanding Shares }\end{array}$ & $8.2 \%$ & $7.1 \%$ & $4.3 \%$ & $19.6 \%$ \\
\hline $\begin{array}{c}\text { Estimated Mean } \\
\text { Percentage of Votes Cast }\end{array} 51$ & $10.6 \%$ & $9.0 \%$ & $5.4 \%$ & $25.0 \%$ \\
\hline $\begin{array}{c}\text { Estimated Median } \\
\text { Percentage of Votes Cast }\end{array}$ & $10.1 \%$ & $8.7 \%$ & $5.4 \%$ & $24.2 \%$ \\
\hline
\end{tabular}

One of the key rights associated with share ownership is, of course, the right to engage in the proxy voting process with respect to those shares. However, while a significant number of shareholders do not vote their shares in annual elections, ${ }^{53}$ the Big Three tend to vote all of their shares. ${ }^{54}$ Because of these phenomena, the proportion of votes cast by the Big Three is greater than their ownership interest. For S\&P 500 companies, prior research indicated that Vanguard's mean voting share was $26 \%$ greater than its mean ownership share, BlackRock's mean voting share was $23 \%$ greater than its mean ownership share, State Street's mean voting share was $22 \%$ greater than its mean ownership share, and the Big Three's combined mean voting share was $24 \%$ greater than its

49. Table 1 is based on percentage of outstanding-share ownership data from Morningstar Investment Research Center accessed on February 23, 2020. MoRningstaR INV. RES. CTR., https://library.morningstar.com/ [https://perma.cc/H9RH-X7LB].

50. The companies included in this data set are the 250 largest publicly traded companies as ranked by Fortune in 2019. Fortune 500, ForTune (2019), https://fortune.com/fortune500/2019/ [https://perma.cc/833F-3UKB].

51. Based upon data demonstrating that the Big Three cast $22 \%$ to $38 \%$ more votes than their mean ownership shares, this Article estimates the Big Three's voting influence in the 250 largest companies as $23 \%$ greater than its ownership share. See Bebchuk \& Hirst, supra note 21 , at 736 .

52. Based upon data demonstrating that the Big Three cast $23 \%$ to $35 \%$ more votes than their median ownership shares, this Article estimates the Big Three's median voting influence in the 250 largest companies as $23 \%$ greater than its median ownership share. See id.

53. See, e.g., Broadridge \& PwC, 2019 Proxy Season Review, ProxyPulse 5 (2019), https://www.broadridge.com/_assets/pdf/broadridge-proxypulse-2019-review.pdf [https:// perma.cc/3YL5-REG7] (finding that only $28 \%$ of shares held by individual investors were voted at annual meetings in 2019).

54. Fisch et al., supra note 40, at 44. 
mean ownership share. ${ }^{55}$ Similarly, Vanguard's median voting share at S\&P 500 companies was $23 \%$ greater than its median ownership share, BlackRock's median voting share was $23 \%$ greater than its median ownership share, State Street's median voting share was $25 \%$ greater than its median ownership share, and the Big Three's combined median voting share was $24 \%$ greater than its median ownership share. ${ }^{56}$ Based upon these rates, this Article estimates that Vanguard alone casts a mean of $10.6 \%$ of votes, BlackRock casts a mean of $9.0 \%$ of votes, and State Street casts a mean of $5.4 \%$ of votes at the largest 250 publicly traded companies in the United States, for a combined total of $25 \%$. Similarly, it estimates Vanguard's median voting influence as $10.1 \%$, BlackRock's median voting influence as $8.7 \%$, and State Street's median voting influence as $5.4 \%$, for a combined total of $24.2 \%$. Such findings are consistent with prior research in this area.

Another dimension of the Big Three's influence over corporate governance comes from their status as large shareholders, which can provide these funds the ability to access and influence management through informal channels. Previous research from 2017 found that the Big Three, taken together, constituted the single largest shareholder at $88 \%$ of S\&P 500 firms. ${ }^{57}$ Table 2 reveals that, as of February 2020, the Big Three taken together constitute the single largest shareholder at $96 \%$ of the largest 250 publicly traded companies. What is more, just one of the trio alone is the single largest shareholder at $78 \%$ of such companies, with Vanguard serving as the single largest shareholder at a staggering $65.6 \%$ of such companies, BlackRock serving as the single largest shareholder at an additional $10.8 \%$ of such companies, and State Street serving as the single largest shareholder at $1.6 \%$ of such companies. Such findings demonstrate that Vanguard alone is the largest shareholder at the majority of the largest publicly traded companies in the United States and that, at a supermajority of such companies, one of the Big Three is the single largest shareholder.

55. Bebchuk \& Hirst, supra note 21, at 736; see also McLaughlin \& Massa, supra note 47.

56. Bebchuk \& Hirst, supra note 21, at 736.

57. Fichtner et al., supra note 3, at 313. 
Table 2: Largest Shareholders at Largest 250 Companies

This Table reports the number and percentage of the 250 largest companies ${ }^{58}$ at which the Big Three serve as the single largest shareholder, taken either singly (first four columns) or in combination (final two columns). ${ }^{59}$

\begin{tabular}{|c|c|c|c|c|c|c|}
\hline Category & Vanguard & BlackRock & $\begin{array}{c}\text { State } \\
\text { Street }\end{array}$ & $\begin{array}{c}\text { One } \\
\text { of Big } \\
\text { Three }\end{array}$ & Big Two & $\begin{array}{c}\text { Big Three } \\
\text { Combined }\end{array}$ \\
\hline Number & 164 & 27 & 4 & 195 & 236 & 240 \\
\hline Percentage & $65.6 \%$ & $10.8 \%$ & $1.6 \%$ & $78 \%$ & $94.4 \%$ & $96 \%$ \\
\hline
\end{tabular}

As these findings reveal, the Big Three have substantial holdings, powerful voting capabilities, and an influential position as the single largest shareholder at most of the 250 largest publicly traded companies in the United States. Many commentators have discussed what will occur if and when the Big Three's holdings and corresponding influence grow. However, an important question is relatively under-discussed: what can the Big Three do with their influence right now? This Article thus turns to an analysis of the present influence of the Big Three.

\section{DATA ON MARGINS FOR 2018-2019 VOTES}

The Big Three own a combined mean of $20.1 \%$ of the 250 largest publicly traded companies, and they cast approximately $25 \%$ of the votes at such companies. ${ }^{60}$ However, the impact that the Big Three have on elections at portfolio companies is a function not only of their voting power but also of the margins for the ballot items under consideration. In relatively uncontroversial outcomes (with greater than $25 \%$ margins), the Big Three will generally not be able to control the outcome, even acting in concert. ${ }^{61}$ In elections with margins within $25 \%$, the Big Three acting together will often have the power to determine the outcome. In elections with margins within 19.6\%, the Big Two (Vanguard and BlackRock) will often have the power to determine the outcome. In elections with margins within $10.6 \%$, Vanguard alone, the Big One, will often have the power to determine the outcome on its own.

Where do the margins in corporate elections currently fall? This Part seeks to answer that question. It provides data on the voting margins for

58. The companies included in this data set are the 250 largest publicly traded companies as ranked by Fortune in 2019. Fortune 500, supra note 50.

59. Table 1 is based on percentage of outstanding-share ownership data from Morningstar Investment Research Center accessed on February 23, 2020. MorningstaR INV. RES. CTR., supra note 49.

60. See supra Table 1.

61. The Big Three may still be able to influence outcomes in other ways outside the formal voting context, such as through engagements. Moreover, the Big Three have substantial reputational power, and the knowledge that one or more of the Big Three is voting a certain way may influence other investors, potentially increasing their influence on formal voting above the $25 \%$ of votes nominally under their control. 
all 511 shareholder proposals at issue at Fortune 250 companies in calendar years 2018 and 2019. It breaks shareholder proposals into three broad categories: environmental proposals, social proposals, and governance proposals. Section IV.A provides data on the margins for environmental proposals, including proposals related to general environmental reporting, climate change, pollution reporting, water stewardship, pesticide reporting, and deforestation. Section IV.B provides data on the margins for social proposals, including proposals related to equality and diversity, political transparency, worker welfare, human rights, privacy and content governance, and other social proposals. Section IV.C provides data on the margins for governance proposals, including proposals related to executive compensation, voting policies, and other governance proposals. Section IV.D provides data on overall margins for all shareholder proposals.

This Part assesses the maximum current impact of the Big Three through formal proxy voting channels. It generally assumes that, as expected given their influence, the Big Three vote on the winning side of a given shareholder proposal. However, in the less common instances when Big Three funds voted with the losing side, the tables below may overstate the influence that the Big Three exert through formal proxy voting, although not through other channels. Consequently, the figures in these tables should be interpreted conservatively as the upper bound of the Big Three's current proxy voting power. However, knowledge of the Big Three's respective voting histories suggests a low error rate. Data on fund voting behavior and shareholder proposal passage rates allows estimation of maximum error rates. For instance, Vanguard and BlackRock supported environmental and social (E\&S) proposals at rates of $7.5 \%$ and $7.1 \%$, respectively; this caps the theoretical maximum rate of "false positives" (i.e., voting for a proposal that does not pass) at $7.5 \%$ and $7.1 \%$ for E\&S proposals at these funds. ${ }^{62}$ Conversely, given that approximately $2.4 \%$ of E\&S proposals passed in the 2018-2019 period, ${ }^{63}$ this caps the theoretical maximum rate of "false negatives" (i.e., voting against a proposal that passes) for E\&S proposals at approximately $2.4 \%$. Given that the considerable influence of these funds means, ceteris paribus, they are far more likely to vote for the winning side than the losing side, the real error rates are likely well below the theoretical maxima. More detailed, fund-specific information is discussed for each subtopic below. Ultimately, the tables that follow are not designed to argue that the members

62. Caleb N. Griffin, Environmental \& Social Voting at Index Funds 25-26 (Feb. 14, 2020) (working paper) (available at https://ssrn.com/abstract_id=3542081). State Street supported $22.7 \%$ of such proposals, capping its maximum error rate at that level. Id. Thus, although State Street is by far the smallest of the big three and the least likely to flip voting outcomes, the data for State Street should be interpreted particularly conservatively.

63. Marc Treviño, 2019 Proxy Season Review: Part 1-Rule 14a-8 Shareholder Proposals, Harv. L. Sch. F. Corp. Governance (July 26, 2019), https://corpgov.law.harvard .edu/2019/07/26/2019-proxy-season-review-part-1-rule-14a-8-shareholder-proposals/ [https:/ /perma.cc/CKK2-GCN2] (stating that, as of the publication date, 17 out of 710 such proposals had passed). 
of the Big Three could have (or did) flip the outcome of any particular proxy vote. Rather, they are designed to provide a market-wide picture of the Big Three's power and to assess the trio's potential influence on different categories of shareholder proposals at the present moment and into the future.

\section{A. Environmental Proposals}

Shareholders are increasingly exercising their right to present corporate boards with recommendations (known as shareholder proposals) that seek to advance certain environmental causes and outcomes. ${ }^{64}$ In calendar years 2018 and 2019, shareholders at the 250 largest publicly traded companies considered fifty-seven different shareholder proposals related to the environment. ${ }^{65}$ These proposals address a wide variety of environmental issues and topics, including climate change, environmental leadership, pollution reporting, water stewardship, sustainability, pesticide reporting, and deforestation. ${ }^{66}$ Only two environmental proposals at issue in 2018 and 2019 received greater than 50\% support; both sought increased reporting on the potential portfolio impacts of climate change. ${ }^{67}$ As a general matter, the Big Three tend not to support environmental proposals. ${ }^{68}$ Despite their lack of support for such proposals, a significant proportion of these proposals were controversial, rather than overwhelmingly opposed by shareholders. The relatively close margins on such proposals mean that the Big Three have the power to substantially increase the number and percentage of passing environmental proposals, given the Big Three's significant voting stakes.

As Table 3 reveals, shareholders that cast even a moderate proportion of votes can already determine the outcome of a significant proportion of environmental proposals. Well over one-tenth of shareholder proposals fell within a $10.6 \%$ margin, meaning that Vanguard alone is in a position to influence the fate of a significant portion of environmental proposals. Proposals that are most susceptible to Vanguard's influence fall in the climate change and sustainability categories. Over one-third of environmental proposals fell within a $19.6 \%$ margin, meaning that Vanguard and BlackRock together have the power to determine the outcome of a substantial minority of environmental proposals. Proposals susceptible to Vanguard and BlackRock's combined influence generally fall in the climate change, sustainability, water stewardship, pesticide reporting, and deforestation categories. Finally, just under half of all environmental proposals are decided by margins of $25 \%$ or less, meaning that the Big Three in concert have significant power to influence the outcomes of environ-

64. See 17 C.F.R. $§ 240.14 a-8$ (2020).

65. Proxy Monitor, supra note 8.

66. Id.

67. Id.

68. Griffin, supra note 62 , at $25-26$ (showing that Vanguard supported $18.9 \%$ of unique environmental proposals, while State Street supported $20.7 \%$ and BlackRock supported $17.1 \%$ of such proposals). 
mental proposals, even without any further growth. Once again, the most controversial and therefore most easily influenced proposals fall in the climate change, sustainability, water stewardship, pesticide reporting, and deforestation categories.

Table 3: Voting Margins on Environmental Proposals 69

This Table provides data on the mean rate of overall shareholder support for environmental shareholder proposals at issue in calendar years 2018 and 2019, as well as the proportion of shareholder proposals that fell within margins of 10.6\% (Big One), 19.6\% (Big Two), and 25\% (Big Three).

\begin{tabular}{|c|c|c|c|c|}
\hline Category & \begin{tabular}{|c|} 
Mean \\
Support
\end{tabular} & Big One & Big Two & Big Three \\
\hline General Environmental & $2.9 \%$ & $\begin{array}{l}0 \text { of } 2 \\
(0 \%)\end{array}$ & $\begin{array}{l}0 \text { of } 2 \\
(0 \%)\end{array}$ & $\begin{array}{l}0 \text { of } 2 \\
(0 \%)\end{array}$ \\
\hline Climate Change & $24.9 \%$ & $\begin{array}{l}7 \text { of } 28 \\
(25 \%)\end{array}$ & \begin{tabular}{|l|}
12 of 28 \\
$(42.9 \%)$
\end{tabular} & $\begin{array}{l}16 \text { of } 28 \\
(57.1 \%)\end{array}$ \\
\hline Environmental Leadership & $13.8 \%$ & $\begin{array}{l}0 \text { of } 3 \\
(0 \%)\end{array}$ & $\begin{array}{l}0 \text { of } 3 \\
(0 \%)\end{array}$ & $\begin{array}{c}1 \text { of } 3 \\
(33.3 \%)\end{array}$ \\
\hline Pollution Reporting & $10.6 \%$ & $\begin{array}{l}0 \text { of } 3 \\
(0 \%)\end{array}$ & $\begin{array}{l}0 \text { of } 3 \\
(0 \%)\end{array}$ & $\begin{array}{l}0 \text { of } 3 \\
(0 \%)\end{array}$ \\
\hline Water Stewardship & $24 \%$ & $\begin{array}{l}0 \text { of } 2 \\
(0 \%)\end{array}$ & $\begin{array}{c}1 \text { of } 2 \\
(50 \%)\end{array}$ & $\begin{array}{c}1 \text { of } 2 \\
(50 \%)\end{array}$ \\
\hline Sustainability & $30.1 \%$ & $\begin{array}{c}2 \text { of } 14 \\
(14.3 \%)\end{array}$ & \begin{tabular}{|c|}
5 of 14 \\
$(35.7 \%)$ \\
\end{tabular} & $\begin{array}{c}8 \text { of } 14 \\
(57.1 \%)\end{array}$ \\
\hline Pesticide Reporting & $18.1 \%$ & $\begin{array}{l}0 \text { of } 3 \\
(0 \%) \\
\end{array}$ & $\begin{array}{c}1 \text { of } 3 \\
(33 \%)\end{array}$ & $\begin{array}{l}1 \text { of } 3 \\
(33 \%)\end{array}$ \\
\hline Deforestation & $21.3 \%$ & $\begin{array}{l}0 \text { of } 2 \\
(0 \%)\end{array}$ & $\begin{array}{c}1 \text { of } 2 \\
(50 \%)\end{array}$ & $\begin{array}{c}1 \text { of } 2 \\
(50 \%)\end{array}$ \\
\hline \multicolumn{2}{|c|}{ Overall Environmental } & $\begin{array}{c}9 \text { of } 57 \\
(15.8 \%)\end{array}$ & \begin{tabular}{|l|}
20 of 57 \\
$(35.1 \%)$
\end{tabular} & $\begin{array}{l}28 \text { of } 57 \\
(49.1 \%)\end{array}$ \\
\hline
\end{tabular}

Data on margins for shareholder environmental proposals suggest that the Big Three are already able to determine the fate of a significant proportion of the environment-related ballot items at issue in a given year. As such, index funds are already shaping corporate decision-making on environmental topics, and their influence is strongest in the areas of the greatest controversy, such as climate change, sustainability, pesticide reporting, deforestation, and water stewardship.

69. Table 3 is based on data on the outcomes of shareholder proposals for the largest 250 U.S. public companies, as ranked by Fortune magazine, collected by Proxy Monitor. PROXY MONITOR, supra note 8. 


\section{B. Social Proposals}

In addition to environmental proposals, shareholders also present for voting a substantial number of proposals related to social topics at annual meetings. In calendar years 2018 and 2019, shareholders at the 250 largest publicly traded companies considered 155 different shareholder proposals related to social causes and issues. ${ }^{70}$ These proposals cover a diverse set of topics, ranging from sexual harassment to animal welfare to tax practices to lobbying transparency.

As is the case with environmental proposals, the Big Three tend not to support shareholder proposals related to social issues and causes. ${ }^{71}$ Among all shareholders, just four of the 155 social proposals at issue in 2018 and 2019 received greater than 50\% support. However, a number of these proposals lost by relatively close margins, meaning that greater support from the Big Three could meaningfully increase the number of victorious proposals. As Table 5 demonstrates, $12.3 \%$ of social proposals had margins of less than $10.6 \%, 34.2 \%$ of social proposals had margins of less than $19.6 \%$, and $49 \%$ of social proposals had margins of $25 \%$ or less. These figures suggest that the Big Three, and particularly Vanguard and BlackRock, already have considerable power to shape corporate behavior through their voting decisions.

70. Id.

71. Vanguard supported $11.4 \%$ of unique diversity \& equality proposals, $6.3 \%$ of unique human rights proposals, $0 \%$ of unique worker welfare proposals, $0 \%$ of unique privacy and content governance proposals, $0 \%$ of unique political transparency proposals, and $20 \%$ of other unique social proposals in the 2018-2019 proxy season. Griffin, supra note 62 , at $25-26$. BlackRock supported $2.9 \%$ of unique diversity \& equality proposals, $6.3 \%$ of unique human rights proposals, $0 \%$ of unique worker welfare proposals, $0 \%$ of unique privacy and content governance proposals, $4.6 \%$ of unique political transparency proposals, and $20 \%$ of unique other social proposals in the 2018-2019 proxy season. Id. State Street supported $24.1 \%$ of unique diversity \& equality proposals, $8.3 \%$ of unique human rights proposals, $0 \%$ of unique worker welfare proposals, $0 \%$ of unique privacy and content governance proposals, $37.8 \%$ of unique political transparency proposals, and $16.7 \%$ of unique other social proposals in the 2018-2019 proxy season. Id. 
Table 4: Voting Margins on All Social Proposals 72

This Table provides data on the proportion of shareholder proposals that fell within margins of 10.6\% (Big One), 19.6\% (Big Two), and 25\% (Big Three).

\begin{tabular}{|c|c|c|c|}
\hline Category & Big One & Big Two & Big Three \\
\hline Equality \& Diversity & $\begin{array}{c}3 \text { of } 30 \\
(10 \%)\end{array}$ & $\begin{array}{c}8 \text { of } 30 \\
(26.7 \%)\end{array}$ & $\begin{array}{c}14 \text { of } 30 \\
(46.7 \%)\end{array}$ \\
\hline Political Transparency & $\begin{array}{c}14 \text { of } 74 \\
(18.9 \%)\end{array}$ & $\begin{array}{c}35 \text { of } 74 \\
(47.3 \%)\end{array}$ & $\begin{array}{c}49 \text { of } 74 \\
(66.2 \%)\end{array}$ \\
\hline Worker Welfare & $\begin{array}{c}0 \text { of } 14 \\
(0 \%)\end{array}$ & $\begin{array}{c}5 \text { of } 14 \\
(35.7 \%)\end{array}$ & $\begin{array}{c}6 \text { of } 14 \\
(42.9 \%)\end{array}$ \\
\hline Human Rights & $\begin{array}{c}0 \text { of } 13 \\
(0 \%)\end{array}$ & $\begin{array}{c}2 \text { of } 13 \\
(15.4 \%)\end{array}$ & $\begin{array}{c}3 \text { of } 13 \\
(23.1 \%)\end{array}$ \\
\hline \multirow{2}{*}{ Privacy \& Content Governance } & $\begin{array}{c}0 \text { of } 7 \\
(0 \%)\end{array}$ & $\begin{array}{c}0 \text { of } 7 \\
(0 \%)\end{array}$ & $\begin{array}{c}1 \text { of } 7 \\
(14.3 \%)\end{array}$ \\
\hline Other Social & $\begin{array}{c}2 \text { of } 17 \\
(11.8 \%)\end{array}$ & $\begin{array}{c}3 \text { of } 17 \\
(17.6 \%)\end{array}$ & $\begin{array}{c}3 \text { of } 17 \\
(17.6 \%)\end{array}$ \\
\hline Overall Social & $\begin{array}{c}19 \text { of } 155 \\
(12.3 \%)\end{array}$ & $\begin{array}{c}53 \text { of } 155 \\
(34.2 \%)\end{array}$ & $\begin{array}{c}76 \text { of } 155 \\
(49.0 \%)\end{array}$ \\
\hline
\end{tabular}

The overall data on margins for social proposals mask considerable variation based on the type of proposal under consideration. As such, additional tables provide more data on the margins for specific categories of social proposals. Table 5 below provides the data on voting margins for equality and diversity proposals. It reveals that $10 \%$ of equality and diversity proposals fell within margins of $10.6 \%$ or less, while $26.7 \%$ fell within margins of $19.6 \%$ or less, and $46.7 \%$ fell within margins of $25 \%$ or less. In particular, proposals concerning employee diversity have considerably closer margins than other proposal types. All seven proposals on employee diversity fell within $25 \%$ margins, $85.7 \%$ of such proposals fell within $19.6 \%$ margins, and $42.9 \%$ of such proposals fell within $10.6 \%$ margins. Considering that Vanguard and BlackRock very rarely support employee diversity proposals, it is clear that increased support by these large index funds could shift the tide on these types of proposals. ${ }^{73}$

72. Table 4 is based on data on the outcomes of shareholder proposals for the largest 250 U.S. public companies, as ranked by Fortune magazine, collected by Proxy Monitor. ProXy Monitor, supra note 8.

73. Griffin, supra note 62 , at 18-19 (finding that Vanguard supported $17.9 \%$ of unique employee diversity reporting proposals while BlackRock supported $0 \%$ of such proposals). 
Table 5: Voting Margins on Equality \& Diversity Proposals ${ }^{74}$

This Table provides data on the mean rate of overall shareholder support for equality and diversity shareholder proposals at issue in calendar years 2018 and 2019, as well as the proportion of shareholder proposals that fell within margins of 10.6\% (Big One), 19.6\% (Big Two), and 25\% (Big Three).

\begin{tabular}{|c|c|c|c|c|}
\hline Category & $\begin{array}{c}\text { Mean } \\
\text { Support }\end{array}$ & Big One & Big Two & Big Three \\
\hline Board Diversity & $7.6 \%$ & $\begin{array}{c}0 \text { of } 7 \\
(0 \%)\end{array}$ & $\begin{array}{c}0 \text { of } 7 \\
(0 \%)\end{array}$ & $\begin{array}{c}1 \text { of } 7 \\
(14.3 \%)\end{array}$ \\
\hline $\begin{array}{c}\text { Gender, Racial and/or } \\
\text { Ethnicity Pay Gap Reporting }\end{array}$ & $22.3 \%$ & $\begin{array}{c}0 \text { of } 16 \\
(0 \%)\end{array}$ & $\begin{array}{c}2 \text { of } 16 \\
(12.5 \%)\end{array}$ & $\begin{array}{c}8 \text { of } 16 \\
(50 \%)\end{array}$ \\
\hline Employee Diversity & $34.6 \%$ & $\begin{array}{c}3 \text { of } 7 \\
(42.9 \%)\end{array}$ & $\begin{array}{c}6 \text { of } 7 \\
(85.7 \%)\end{array}$ & $\begin{array}{c}7 \text { of } 7 \\
(100 \%)\end{array}$ \\
\hline \multicolumn{2}{|c|}{ Overall Equality \& Diversity } & $\begin{array}{c}3 \text { of } 30 \\
(10 \%)\end{array}$ & $\begin{array}{c}8 \text { of } 30 \\
(26.7 \%)\end{array}$ & $\begin{array}{c}14 \text { of } 30 \\
(46.7 \%)\end{array}$ \\
\hline
\end{tabular}

Margins for political transparency proposals tend to be relatively slim. Nearly one-fifth of such proposals fell within $10.6 \%$ margins, nearly onehalf fell within $19.6 \%$ margins, and nearly two-thirds fell within $25 \%$ margins. Given that Vanguard and BlackRock almost never support political transparency proposals, their support could mean that nearly half of such proposals achieve majority support, and Vanguard alone has the power to ensure that nearly $20 \%$ of such proposals have majority support. ${ }^{75}$ In practice, this means that Vanguard's and BlackRock's decisions not to support political transparency proposals prevent the passage of many of these proposals.

74. Table 5 is based on data on the outcomes of shareholder proposals for the largest 250 U.S. public companies, as ranked by Fortune magazine, collected by Proxy Monitor. PROXY MONITOR, supra note 8.

75. Griffin, supra note 62 , at 25-26 (finding that Vanguard supported $0 \%$ of unique political transparency proposals while BlackRock supported $4.6 \%$ of such proposals). 
Table 6: Voting Margins on Political Transparency Proposals

This Table provides data on the mean rate of overall shareholder support for political transparency shareholder proposals at issue in calendar years 2018 and 2019, as well as the proportion of shareholder proposals that fell within margins of 10.6\% (Big One), 19.6\% (Big Two), and 25\% (Big Three).

\begin{tabular}{|c|c|c|c|c|}
\hline Category & $\begin{array}{c}\text { Mean } \\
\text { Support }\end{array}$ & Big One & Big Two & Big Three \\
\hline $\begin{array}{c}\text { Political Contribution } \\
\text { Disclosure }\end{array}$ & $33.4 \%$ & $\begin{array}{c}10 \text { of } 25 \\
(40 \%)\end{array}$ & $\begin{array}{c}14 \text { of } 25 \\
(56 \%)\end{array}$ & $\begin{array}{c}19 \text { of } 25 \\
(76 \%)\end{array}$ \\
\hline Lobbying Transparency & $26.6 \%$ & $\begin{array}{c}4 \text { of } 48 \\
(8.3 \%)\end{array}$ & $\begin{array}{c}21 \text { of } 48 \\
(43.8 \%)\end{array}$ & $\begin{array}{c}30 \text { of } 48 \\
(62.5 \%)\end{array}$ \\
\hline $\begin{array}{c}\text { Advisory Vote on } \\
\text { Political Contributions }\end{array}$ & $5.9 \%$ & $\begin{array}{c}0 \text { of } 1 \\
(0 \%)\end{array}$ & $\begin{array}{c}0 \text { of } 1 \\
(0 \%)\end{array}$ & $\begin{array}{c}0 \text { of } 1 \\
(0 \%)\end{array}$ \\
\hline \multicolumn{2}{|c|}{ Overall Political Transparency } & $\begin{array}{c}14 \text { of } 74 \\
(18.9 \%)\end{array}$ & $\begin{array}{c}35 \text { of } 74 \\
(47.3 \%)\end{array}$ & $\begin{array}{c}49 \text { of } 74 \\
(66.2 \%)\end{array}$ \\
\hline
\end{tabular}

Margins for worker welfare proposals are somewhat wider. None of the proposals studied had margins less than $10.6 \%$, over one-third had margins of $19.6 \%$, and nearly half had margins of $25 \%$ or less. However, because Vanguard, BlackRock, and State Street are united in failing to support almost any worker welfare proposals, the trio has considerable power to change the fate of such proposals. ${ }^{76}$ In particular, their support could mean that proposals seeking increased transparency on forced labor and prison labor in the supply chain, pay equity between CEOs and other employees, and sexual harassment reporting gain enough support to pass. In this way, worker welfare proposals are determined in large part by the decisions of the Big Three's stewardship teams.

75. Table 6 is based on data on the outcomes of shareholder proposals for the largest 250 U.S. public companies, as ranked by Fortune magazine, collected by Proxy Monitor. Proxy Monitor, supra note 8.

76. Griffin, supra note 62, at 25-26 (finding that Vanguard, BlackRock, and State Street support $0 \%$ of worker welfare proposals). 
Table 7: Voting Margins on Worker Welfare Proposals 77

This Table provides data on the mean rate of overall shareholder support for worker welfare proposals at issue in calendar years 2018 and 2019, as well as the proportion of shareholder proposals that fell within margins of 10.6\% (Big One), 19.6\% (Big Two), and 25\% (Big Three).

\begin{tabular}{|c|c|c|c|c|}
\hline Category & $\begin{array}{l}\text { Mean } \\
\text { Support }\end{array}$ & Big One & Big Two & Big Three \\
\hline $\begin{array}{l}\text { Forced Labor \& Prison } \\
\text { Labor in Supply Chain }\end{array}$ & $22.5 \%$ & $\begin{array}{l}0 \text { of } 7 \\
(0 \%)\end{array}$ & $\begin{array}{c}3 \text { of } 7 \\
(42.9 \%)\end{array}$ & $\begin{array}{c}4 \text { of } 7 \\
(57.1 \%)\end{array}$ \\
\hline Sexual Harassment & $25.1 \%$ & $\begin{array}{l}0 \text { of } 2 \\
(0 \%)\end{array}$ & $\begin{array}{l}1 \text { of } 2 \\
(50 \%)\end{array}$ & $\begin{array}{l}1 \text { of } 2 \\
(50 \%)\end{array}$ \\
\hline Pay Equity & $34.8 \%$ & $\begin{array}{l}0 \text { of } 2 \\
(0 \%)\end{array}$ & $\begin{array}{c}1 \text { of } 2 \\
(50 \%)\end{array}$ & $\begin{array}{l}1 \text { of } 2 \\
(50 \%)\end{array}$ \\
\hline Employment Practices & $5.6 \%$ & $\begin{array}{l}0 \text { of } 3 \\
(0 \%)\end{array}$ & $\begin{array}{l}0 \text { of } 3 \\
(0 \%)\end{array}$ & $\begin{array}{l}0 \text { of } 3 \\
(0 \%)\end{array}$ \\
\hline \multicolumn{2}{|c|}{ Overall Worker Welfare } & $\begin{array}{c}0 \text { of } 14 \\
(0 \%)\end{array}$ & $\begin{array}{c}5 \text { of } 14 \\
(35.7 \%)\end{array}$ & $\begin{array}{c}6 \text { of } 14 \\
(42.9 \%)\end{array}$ \\
\hline
\end{tabular}

Human rights proposals generally lose by significant margins. Table 8 below shows that none of the proposals studied fell within $10.6 \%$ margins, $15 \%$ fell within $19.6 \%$ margins, and nearly $25 \%$ fell within $25 \%$ margins. However, margins tend to be closer for human rights reporting proposals, with nearly one-half falling within $25 \%$ margins and over onequarter falling within $19.6 \%$ margins. Because the Big Three very rarely support human rights proposals, their lack of support is determinative in a significant proportion of contests, even given the wide margins on such proposals. ${ }^{78}$

77. Table 7 is based on data on the outcomes of shareholder proposals for the largest 250 U.S. public companies, as ranked by Fortune magazine, collected by Proxy Monitor. Proxy Monitor, supra note 8.

78. Griffin, supra note 62, at 25-26 (finding that Vanguard and BlackRock both supported $6.3 \%$ of unique human rights proposals while State Street supported $8.3 \%$ of such proposals). 
Table 8: Voting Margins on Human Rights Proposals 79

This Table provides data on the mean rate of overall shareholder support for human rights proposals at issue in calendar years 2018 and 2019, as well as the proportion of shareholder proposals that fell within margins of 10.6\% (Big One), 19.6\% (Big Two), and 25\% (Big Three).

\begin{tabular}{|c|c|c|c|c|}
\hline Category & $\begin{array}{c}\text { Mean } \\
\text { Support }\end{array}$ & Big One & Big Two & Big Three \\
\hline $\begin{array}{c}\text { Human Rights } \\
\text { Reporting }\end{array}$ & $16.8 \%$ & $\begin{array}{c}0 \text { of } 7 \\
(0 \%)\end{array}$ & $\begin{array}{c}2 \text { of } 7 \\
(28.3 \%)\end{array}$ & $\begin{array}{c}3 \text { of } 7 \\
(42.9 \%)\end{array}$ \\
\hline $\begin{array}{c}\text { Human Rights } \\
\text { Leadership }\end{array}$ & $6.7 \%$ & $\begin{array}{c}0 \text { of } 6 \\
(0 \%)\end{array}$ & $\begin{array}{c}0 \text { of } 6 \\
(0 \%)\end{array}$ & $\begin{array}{c}0 \text { of } 6 \\
(0 \%)\end{array}$ \\
\hline \multicolumn{2}{|c|}{ Overall Human Rights } & $\begin{array}{c}0 \text { of } 13 \\
(0 \%)\end{array}$ & $\begin{array}{c}2 \text { of } 13 \\
(15.4 \%)\end{array}$ & $\begin{array}{c}3 \text { of } 13 \\
(23.1 \%)\end{array}$ \\
\hline
\end{tabular}

As Table 9 demonstrates, proposals related to privacy and content governance almost never receive a significant percentage of support from shareholders overall. Although the Big Three almost never support such proposals, ${ }^{80}$ because so few other shareholders support them, the Big Three's decisions regarding privacy and content governance proposals tend to have little independent influence on the outcomes of these types of proposals. However, it is possible that the occasional proposal achieves enough support that the combined support of the Big Three could tip the balance.

79. Table 8 is based on data on the outcomes of shareholder proposals for the largest 250 U.S. public companies, as ranked by Fortune magazine, collected by Proxy Monitor. PROXY MONITOR, supra note 8.

80. Griffin, supra note 62, at 25-26 (finding that Vanguard, BlackRock and State Street supported $0 \%$ of privacy and content governance proposals). 


\section{Table 9: Voting Margins on Privacy \& Content Governance Proposals ${ }^{81}$}

This Table provides data on the mean rate of overall shareholder support for privacy and content governance proposals at issue in calendar years 2018 and 2019, as well as the proportion of shareholder proposals that fell within margins of 10.6\% (Big One), 19.6\% (Big Two), and 25\% (Big Three).

\begin{tabular}{|c|c|c|c|c|}
\hline Category & $\begin{array}{c}\text { Mean } \\
\text { Support }\end{array}$ & Big One & Big Two & Big Three \\
\hline Privacy-Related & $10 \%$ & $\begin{array}{c}0 \text { of } 3 \\
(0 \%)\end{array}$ & $\begin{array}{c}0 \text { of } 3 \\
(0 \%)\end{array}$ & $\begin{array}{c}1 \text { of } 3 \\
(33.3 \%)\end{array}$ \\
\hline $\begin{array}{c}\text { Report on Content } \\
\text { Governance }\end{array}$ & $8.9 \%$ & $\begin{array}{c}0 \text { of } 4 \\
(0 \%)\end{array}$ & $\begin{array}{c}0 \text { of } 4 \\
(0 \%)\end{array}$ & $\begin{array}{c}0 \text { of } 4 \\
(0 \%)\end{array}$ \\
\hline \multicolumn{2}{|c|}{$\begin{array}{c}\text { Overall Privacy \& } \\
\text { Content Governance }\end{array}$} & $\begin{array}{c}0 \text { of } 7 \\
(0 \%)\end{array}$ & $\begin{array}{c}0 \text { of } 7 \\
(0 \%)\end{array}$ & $\begin{array}{c}1 \text { of } 7 \\
(14.3 \%)\end{array}$ \\
\hline
\end{tabular}

In addition to the aforementioned categories for social proposals, shareholders considered a number of other types of social proposals in calendar years 2018 and 2019 that did not fit neatly in the above categories. These include two proposals seeking annual reporting on charitable contributions, two proposals seeking reporting on tax practices, two proposals seeking reporting on activities in conflict-affected areas of certain nation-states, two proposals seeking improved animal welfare practices, one proposal seeking increased transparency on the pricing of consumer goods, one proposal seeking support for cannabis descheduling, and seven proposals related to public health initiatives. These proposals (with the exception of public health proposals) tended to receive little support from shareholders. Over one-quarter of public health proposals had margins within $10.6 \%$, while nearly one-half had margins within $19.6 \%$. Given that Vanguard and BlackRock rarely support such proposals, increased support by these funds could be pivotal for public health proposals. ${ }^{82}$

81. Table 9 is based on data on the outcomes of shareholder proposals for the largest 250 U.S. public companies, as ranked by Fortune magazine, collected by Proxy Monitor. ProXY MONITOR, supra note 8

82. Griffin, supra note 62 , at 23 (finding that Vanguard supported $14.3 \%$ of public health proposals, BlackRock supported $22.2 \%$ of public health proposals, and State Street supported $25 \%$ of public health proposals). 
Table 10: Voting Margins on Other Social Proposals 83

This Table provides data on the mean rate of overall shareholder support for other social proposals at issue in calendar years 2018 and 2019, as well as the proportion of shareholder proposals that fell within margins of 10.6\% (Big One), 19.6\% (Big Two), and 25\% (Big Three).

\begin{tabular}{|c|c|c|c|c|}
\hline Category & $\begin{array}{c}\text { Mean } \\
\text { Support }\end{array}$ & Big One & Big Two & Big Three \\
\hline $\begin{array}{c}\text { Report on } \\
\text { Charitable Giving }\end{array}$ & $2.1 \%$ & $\begin{array}{l}0 \text { of } 2 \\
(0 \%)\end{array}$ & $\begin{array}{l}0 \text { of } 2 \\
(0 \%)\end{array}$ & $\begin{array}{l}0 \text { of } 2 \\
(0 \%)\end{array}$ \\
\hline Report on Tax Practices & $1.8 \%$ & $\begin{array}{l}0 \text { of } 2 \\
(0 \%)\end{array}$ & $\begin{array}{l}0 \text { of } 2 \\
(0 \%)\end{array}$ & $\begin{array}{l}0 \text { of } 2 \\
(0 \%)\end{array}$ \\
\hline $\begin{array}{l}\text { Report on Activities } \\
\text { in Conflict Zones }\end{array}$ & $7.5 \%$ & $\begin{array}{l}0 \text { of } 2 \\
(0 \%)\end{array}$ & $\begin{array}{l}0 \text { of } 2 \\
(0 \%)\end{array}$ & $\begin{array}{l}0 \text { of } 2 \\
(0 \%)\end{array}$ \\
\hline Animal Welfare & $5 \%$ & $\begin{array}{l}0 \text { of } 2 \\
(0 \%)\end{array}$ & $\begin{array}{l}0 \text { of } 2 \\
(0 \%)\end{array}$ & $\begin{array}{l}0 \text { of } 2 \\
(0 \%)\end{array}$ \\
\hline $\begin{array}{c}\text { Pricing } \\
\text { Transparency }\end{array}$ & $0 \%$ & $\begin{array}{l}0 \text { of } 1 \\
(0 \%)\end{array}$ & $\begin{array}{l}0 \text { of } 1 \\
(0 \%)\end{array}$ & $\begin{array}{l}0 \text { of } 1 \\
(0 \%)\end{array}$ \\
\hline $\begin{array}{l}\text { Support for Cannabis } \\
\text { Descheduling }\end{array}$ & $1.6 \%$ & $\begin{array}{l}0 \text { of } 1 \\
(0 \%)\end{array}$ & $\begin{array}{l}0 \text { of } 1 \\
(0 \%)\end{array}$ & $\begin{array}{l}0 \text { of } 1 \\
(0 \%)\end{array}$ \\
\hline Public Health & $24.4 \%$ & $\begin{array}{c}2 \text { of } 7 \\
(28.6 \%)\end{array}$ & $\begin{array}{c}3 \text { of } 7 \\
(42.9 \%)\end{array}$ & $\begin{array}{c}3 \text { of } 7 \\
(42.9 \%)\end{array}$ \\
\hline \multicolumn{2}{|c|}{ Overall Other Social } & $\begin{array}{c}2 \text { of } 17 \\
(11.8 \%)\end{array}$ & $\begin{array}{c}3 \text { of } 17 \\
(17.6 \%)\end{array}$ & $\begin{array}{c}3 \text { of } 17 \\
(17.6 \%)\end{array}$ \\
\hline
\end{tabular}

Overall, the Big Three, particularly Vanguard and BlackRock, are already in a position to significantly impact the outcomes of a great proportion of social proposals. Their significant holdings, and the relatively small margins for a number of controversial proposals, imply that the Big Three are already in a position to decide numerous corporate controversies. This influence is especially pronounced on proposals related to equality and diversity, worker welfare, and political transparency, but their effect can also be seen on public health proposals, human rights proposals, and some privacy and content governance proposals. It is clear that the Big Three already have the capacity to determine the outcomes of a considerable proportion of proxy votes.

\section{Governance Proposals}

Shareholders proposed 299 different proposals related to governance matters. ${ }^{84}$ Fifty-two of such proposals addressed topics related to execu-

83. Table 10 is based on data on the outcomes of shareholder proposals for the largest 250 U.S. public companies, as ranked by Fortune magazine, collected by Proxy Monitor. Proxy Monitor, supra note 8.

84. Id. 
tive compensation. ${ }^{85}$ An additional thirty proposals addressed the mechanics of voting at annual meetings. ${ }^{86}$ Further, 217 proposals addressed a variety of other topics, such as the right to act by written consent and the ownership percentage required to call special meetings. ${ }^{87}$ Overall, almost one-quarter of governance proposals won or lost by margins of less than $10.6 \%$, just over half won or lost by margins of less than $19.6 \%$, and almost two-thirds won or lost by margins of $25 \%$. Because the Big Three's voting patterns on governance-related topics are more variable than their (at least for the Big Two) near-uniform opposition to environmental and social proposals, theoretical error rates (although perhaps not real error rates) are higher. ${ }^{88}$ Thus, the tables below are not designed to predict the outcome of a particular proxy vote, but to demonstrate that the Big Three's voting decisions have a pivotal impact on the marketwide outcomes of governance proposals.

\section{Table 11: Voting Margins on All Governance Proposals ${ }^{89}$}

This Table provides data on the proportion of shareholder proposals related to governance that fell within margins of 10.6\% (Big One), 19.6\% (Big Two), and 25\% (Big Three).

\begin{tabular}{|c|c|c|c|}
\hline Category & Big One & Big Two & Big Three \\
\hline \multirow{2}{*}{ Executive Compensation } & $\begin{array}{c}3 \text { of } 52 \\
(5.7 \%)\end{array}$ & $\begin{array}{c}12 \text { of } 52 \\
(23.1 \%)\end{array}$ & $\begin{array}{c}20 \text { of } 52 \\
(38.5 \%)\end{array}$ \\
\hline \multirow{2}{*}{ Voting Policies \& Practices } & $\begin{array}{c}1 \text { of } 30 \\
(3.3 \%)\end{array}$ & $\begin{array}{c}4 \text { of } 30 \\
(13.3 \%)\end{array}$ & $\begin{array}{c}12 \text { of } 30 \\
(40 \%)\end{array}$ \\
\hline Other Governance & $\begin{array}{c}68 \text { of } 217 \\
(31.3 \%)\end{array}$ & $\begin{array}{c}135 \text { of } 217 \\
(62.2 \%)\end{array}$ & $\begin{array}{c}163 \text { of } 217 \\
(75.1 \%)\end{array}$ \\
\hline Overall Governance & $\begin{array}{c}72 \text { of } 299 \\
(24.1 \%)\end{array}$ & $\begin{array}{c}151 \text { of } 299 \\
(50.5 \%)\end{array}$ & $\begin{array}{c}195 \text { of } 299 \\
(65.2 \%)\end{array}$ \\
\hline
\end{tabular}

85. Id.

86. Id.

87. $I d$.

88. For instance, Vanguard reports that in 2019 , it supported $7 \%$ of "environmental/ social" shareholder proposals compared to $42 \%$ of "governance-related" proposals, $22 \%$ of "board-related" proposals, and 3\% of "compensation-related" proposals. VANGUARD 2019 InVestment StewARdship Report, supra note 31, at 29. State Street reports that it supported approximately $27 \%$ of "environmental and social related" proposals, approximately $28 \%$ of "governance-related" proposals, approximately $5 \%$ of "directors-related" proposals, approximately $62 \%$ of "compensation-related" proposals, and approximately 14\% of "routine business" shareholder proposals. State Street 2019 InVEstment SteWARDSHIP REPORT, supra note 31, at 10. BlackRock's investment stewardship report does not provide category-specific data on support for shareholder proposals. See BlackRock Investment Stewardship, supra note 31, at 14. Overall, better reporting of aggregated proxy voting data would considerably enhance transparency in this area.

89. Table 11 is based on data on the outcomes of shareholder proposals for the largest 250 U.S. public companies, as ranked by Fortune magazine, collected by Proxy Monitor. ProXy MONITOR, supra note 8. 
As Table 12 highlights, margins for proposals related to executive compensation were larger than those for governance as a whole. Just $5 \%$ of such proposals were decided by margins of $10.6 \%$ or less, nearly onequarter were decided by margins of $19.6 \%$ or less, and just over one-third were decided by margins of $25 \%$ or less. However, overall statistics mask considerable variation based upon the type of proposal. In particular, proposals related to clawbacks, equity compensation rules, and golden parachutes had especially narrow margins. Nearly half of all clawback proposals had margins of less than $10.6 \%$, while over two-thirds had margins of $19.6 \%$ or less. Similarly, one-quarter of proposals related to equity compensation rules had margins less than $19.6 \%$, and half of such proposals had margins less than $25 \%$. In addition, three-quarters of proposals related to golden parachutes had margins less than $19.6 \%$. In these areas, the decisions of stewardship teams at the Big Three are of considerable import.

\section{Table 12: Voting Margins on Executive Compensation Proposals ${ }^{90}$}

This Table provides data on the mean rate of overall shareholder support for executive compensation proposals at issue in calendar years 2018 and 2019, as well as the proportion of shareholder proposals that fell within margins of 10.6\% (Big One), 19.6\% (Big Two), and 25\% (Big Three).

\begin{tabular}{|c|c|c|c|c|}
\hline Category & $\begin{array}{c}\text { Mean } \\
\text { Support }\end{array}$ & Big One & Big Two & Big Three \\
\hline Change Clawback Policy & $33.1 \%$ & $\begin{array}{c}3 \text { of } 7 \\
(42.9 \%)\end{array}$ & $\begin{array}{c}5 \text { of } 7 \\
(71.4 \%)\end{array}$ & $\begin{array}{c}5 \text { of } 7 \\
(71.4 \%)\end{array}$ \\
\hline $\begin{array}{c}\text { Equity Compensation } \\
\text { Rules }\end{array}$ & $24.1 \%$ & $\begin{array}{c}0 \text { of } 12 \\
(0 \%)\end{array}$ & $\begin{array}{c}4 \text { of } 12 \\
(25 \%)\end{array}$ & $\begin{array}{c}6 \text { of } 12 \\
(50 \%)\end{array}$ \\
\hline $\begin{array}{c}\text { Report on Executive } \\
\text { Compensation }\end{array}$ & $6.8 \%$ & $\begin{array}{c}0 \text { of } 2 \\
(0 \%)\end{array}$ & $\begin{array}{c}0 \text { of } 2 \\
(0 \%)\end{array}$ & $\begin{array}{c}0 \text { of } 2 \\
(0 \%)\end{array}$ \\
\hline $\begin{array}{c}\text { Consider Pay of All } \\
\text { Employees in Setting } \\
\text { Executive Pay }\end{array}$ & $8.4 \%$ & $\begin{array}{c}0 \text { of } 3 \\
(0 \%)\end{array}$ & $\begin{array}{c}0 \text { of } 3 \\
(0 \%)\end{array}$ & $\begin{array}{c}0 \text { of } 3 \\
(0 \%)\end{array}$ \\
\hline $\begin{array}{c}\text { Require Shareholder } \\
\text { Approval of or Prohibit } \\
\text { Golden Parachutes }\end{array}$ & $34.1 \%$ & $\begin{array}{c}0 \text { of } 4 \\
(0 \%)\end{array}$ & $\begin{array}{c}3 \text { of } 4 \\
(75 \%)\end{array}$ & $\begin{array}{c}4 \text { of } 4 \\
(100 \%)\end{array}$ \\
\hline $\begin{array}{c}\text { Performance Metrics } \\
\text { Requirements }\end{array}$ & $15.3 \%$ & $\begin{array}{c}0 \text { of } 24 \\
(0 \%)\end{array}$ & $\begin{array}{c}0 \text { of } 24 \\
(0 \%)\end{array}$ & $\begin{array}{c}5 \text { of } 24 \\
(20.8 \%)\end{array}$ \\
\hline $\begin{array}{c}\text { Overall Executive Compensation } \\
\text { Oof } 52 \\
(5.7 \%)\end{array}$ & $\begin{array}{c}12 \text { of } 52 \\
(23.1 \%)\end{array}$ & $\begin{array}{c}20 \text { of } 52 \\
(38.5 \%)\end{array}$ \\
\hline
\end{tabular}

90. Table 12 is based on data on the outcomes of shareholder proposals for the largest 250 U.S. public companies, as ranked by Fortune magazine, collected by Proxy Monitor. Id. 
As Table 13 highlights, margins on proposals related to voting practices and procedures were relatively wide. Just one such proposal was decided by margins of $10.6 \%$ or less, four (or $13.3 \%$ ) were decided by margins of $19.6 \%$ or less, and twelve (or $40 \%$ ) were decided by margins of $25 \%$ or less. Only three of seven categories had margins that suggest these proposals are within the Big Three's influence: proposals seeking the elimination of a dual-class stock structure, proposals seeking simple majority voting, and proposals seeking majority voting for the election of directors. One-third of proposals seeking the elimination of the dual-class structure were within $19.6 \%$ margins, while over three-quarters were within the $25 \%$ margin. One-tenth of proposals seeking simple majority voting were within $10.6 \%$ margins, while four-tenths were within $25 \%$ margins. Finally, one of two proposals seeking simple majority voting for director elections had margins of less than $25 \%$. In these areas, the Big Three's substantial holdings give them the power to influence voting outcomes. 
Table 13: Voting Margins on Voting-Related Proposals 91

This Table provides data on the mean rate of overall shareholder support for proposals related to voting policies and procedures at issue in calendar years 2018 and 2019, as well as the proportion of shareholder proposals that fell within margins of 10.6\% (Big One), 19.6\% (Big Two), and 25\% (Big Three).

\begin{tabular}{|c|c|c|c|c|}
\hline Category & $\begin{array}{c}\text { Mean } \\
\text { Support }\end{array}$ & Big One & Big Two & Big Three \\
\hline $\begin{array}{c}\text { Executive Pay } \\
\text { Confidential Voting }\end{array}$ & $4.2 \%$ & $\begin{array}{l}0 \text { of } 1 \\
(0 \%)\end{array}$ & $\begin{array}{l}0 \text { of } 1 \\
(0 \%)\end{array}$ & $\begin{array}{l}0 \text { of } 1 \\
(0 \%)\end{array}$ \\
\hline Cumulative Voting & $8.9 \%$ & $\begin{array}{l}0 \text { of } 5 \\
(0 \%)\end{array}$ & $\begin{array}{l}0 \text { of } 5 \\
(0 \%)\end{array}$ & $\begin{array}{l}0 \text { of } 5 \\
(0 \%)\end{array}$ \\
\hline Director Tenure Limit & $5.4 \%$ & $\begin{array}{l}0 \text { of } 1 \\
(0 \%)\end{array}$ & $\begin{array}{l}0 \text { of } 1 \\
(0 \%)\end{array}$ & $\begin{array}{l}0 \text { of } 1 \\
(0 \%)\end{array}$ \\
\hline $\begin{array}{c}\text { Eliminate Dual-Class } \\
\text { Stock Structure }\end{array}$ & $29.8 \%$ & $\begin{array}{l}0 \text { of } 9 \\
(0 \%)\end{array}$ & $\begin{array}{c}3 \text { of } 9 \\
(33.3 \%) \\
\end{array}$ & $\begin{array}{c}7 \text { of } 9 \\
(77.8 \%)\end{array}$ \\
\hline Simple Majority Voting & $60.5 \%$ & $\begin{array}{l}1 \text { of } 10 \\
(10 \%)\end{array}$ & $\begin{array}{l}1 \text { of } 10 \\
(10 \%)\end{array}$ & $\begin{array}{l}4 \text { of } 10 \\
(40 \%)\end{array}$ \\
\hline $\begin{array}{l}\text { Majority Voting for } \\
\text { Director Elections }\end{array}$ & $27.4 \%$ & $\begin{array}{l}0 \text { of } 2 \\
(0 \%)\end{array}$ & $\begin{array}{l}0 \text { of } 2 \\
(0 \%)\end{array}$ & $\begin{array}{l}1 \text { of } 2 \\
(50 \%)\end{array}$ \\
\hline $\begin{array}{l}\text { Eliminate Formula } \\
\text { Swapping }\end{array}$ & $6.2 \%$ & $\begin{array}{l}0 \text { of } 2 \\
(0 \%)\end{array}$ & $\begin{array}{l}0 \text { of } 2 \\
(0 \%)\end{array}$ & $\begin{array}{l}0 \text { of } 2 \\
(0 \%)\end{array}$ \\
\hline \multicolumn{2}{|c|}{ Overall Voting-Related } & $\begin{array}{l}1 \text { of } 30 \\
(3.3 \%)\end{array}$ & $\begin{array}{c}4 \text { of } 30 \\
(13.3 \%)\end{array}$ & $\begin{array}{c}12 \text { of } 30 \\
(40 \%)\end{array}$ \\
\hline
\end{tabular}

As Table 14 demonstrates, margins varied substantially on proposals related to other governance topics. Proposals related to chairperson independence, declassifying the board, ownership percentages to call special meetings, and the right to act by written consent had the narrowest margins. In the subset of proposals addressing chairperson independence, $15.2 \%$ were within $10.6 \%$ margins, over one-half were within $19.6 \%$ margins, and nearly three-quarters were within $25 \%$ margins. One of the two proposals on declassifying the board had margins of less than $10.6 \%$, while the other proposal had margins of less than $25 \%$. Over half of proposals to reduce the threshold to call a special meeting had margins of less than $10.6 \%$, nearly nine-tenths had margins of less than $19.6 \%$, and nearly $94 \%$ of such proposals had margins of less than $25 \%$. Proposals regarding the right to act by written consent had margins of $10.6 \%$ or less in more than half of cases, $82 \%$ had margins of less than $19.6 \%$, and $86 \%$ had margins of less than $25 \%$. Proposals in these categories are clearly within the influence of the Big Three. In addition, proposals seeking to

91. Table 13 is based on data on the outcomes of shareholder proposals for the largest 250 U.S. public companies, as ranked by Fortune magazine, collected by Proxy Monitor. Id. 
amend proxy access and those seeking shareholder input on bylaw changes were also frequently within the influence of the Big Three. Onequarter of proposals related to proxy access were within $19.6 \%$ margins, while half were within $25 \%$ margins. In addition, one of the two proposals seeking shareholder input on bylaws had margins of less than $19.6 \%$. The seven proposals in other categories (alternatives to maximize shareholder value, risk oversight committee, reporting on stock buybacks, corporate structure reform, and shareholder input on corporate structure reform) had margins so wide as to be outside of the Big Three's range of influence. Overall, the Big Three have the ability to impact a substantial portion of proposals related to other governance topics. 
Table 14: Voting Margins on Other Governance Proposals 92

This Table provides data on the mean rate of overall shareholder support for proposals related to other governance topics in calendar years 2018 and 2019, as well as the proportion of shareholder proposals that fell within margins of 10.6\% (Big One), 19.6\% (Big Two), and 25\% (Big Three).

\begin{tabular}{|c|c|c|c|c|}
\hline Category & \begin{tabular}{|c|} 
Mean \\
Support
\end{tabular} & Big One & Big Two & Big Three \\
\hline $\begin{array}{c}\text { Alternatives to Maximize } \\
\text { Shareholder Value }\end{array}$ & $0.6 \%$ & $\begin{array}{l}0 \text { of } 2 \\
(0 \%)\end{array}$ & $\begin{array}{l}0 \text { of } 2 \\
(0 \%)\end{array}$ & $\begin{array}{l}0 \text { of } 2 \\
(0 \%)\end{array}$ \\
\hline Chairperson Independence & $30.1 \%$ & \begin{tabular}{|l|}
12 of 79 \\
$(15.2 \%)$
\end{tabular} & $\begin{array}{l}41 \text { of } 79 \\
(51.9 \%)\end{array}$ & $\begin{array}{l}57 \text { of } 79 \\
(72.2 \%)\end{array}$ \\
\hline Declassify the Board & $67.1 \%$ & $\begin{array}{l}1 \text { of } 2 \\
(50 \%)\end{array}$ & $\begin{array}{l}1 \text { of } 2 \\
(50 \%)\end{array}$ & $\begin{array}{c}2 \text { of } 2 \\
(100 \%)\end{array}$ \\
\hline Risk Oversight Committee & $10.2 \%$ & $\begin{array}{l}0 \text { of } 2 \\
(0 \%)\end{array}$ & $\begin{array}{l}0 \text { of } 2 \\
(0 \%)\end{array}$ & $\begin{array}{l}0 \text { of } 2 \\
(0 \%)\end{array}$ \\
\hline Report on Stock Buybacks & $5.6 \%$ & $\begin{array}{l}0 \text { of } 1 \\
(0 \%)\end{array}$ & $\begin{array}{l}0 \text { of } 1 \\
(0 \%)\end{array}$ & $\begin{array}{l}0 \text { of } 1 \\
(0 \%)\end{array}$ \\
\hline Corporation Structure Reform & $13.5 \%$ & $\begin{array}{l}0 \text { of } 1 \\
(0 \%)\end{array}$ & $\begin{array}{l}0 \text { of } 1 \\
(0 \%)\end{array}$ & $\begin{array}{l}0 \text { of } 1 \\
(0 \%)\end{array}$ \\
\hline Proxy Access Amendments & $27.5 \%$ & $\begin{array}{c}0 \text { of } 28 \\
(0 \%)\end{array}$ & $\begin{array}{l}7 \text { of } 28 \\
(25 \%)\end{array}$ & $\begin{array}{c}14 \text { of } 28 \\
(50 \%)\end{array}$ \\
\hline Shareholder Input on Bylaws & $22.6 \%$ & $\begin{array}{l}0 \text { of } 2 \\
(0 \%)\end{array}$ & $\begin{array}{l}1 \text { of } 2 \\
(50 \%)\end{array}$ & $\begin{array}{l}1 \text { of } 2 \\
(50 \%)\end{array}$ \\
\hline $\begin{array}{c}\text { Require Shareholder } \\
\text { Approval of Board Size } \\
\text { Change } \\
\end{array}$ & $7.7 \%$ & $\begin{array}{l}0 \text { of } 1 \\
(0 \%)\end{array}$ & $\begin{array}{l}0 \text { of } 1 \\
(0 \%)\end{array}$ & $\begin{array}{l}0 \text { of } 1 \\
(0 \%)\end{array}$ \\
\hline $\begin{array}{c}\text { Reduce Ownership } \\
\text { Percentage to Call Special } \\
\text { Meetings }\end{array}$ & $41 \%$ & $\begin{array}{l}28 \text { of } 49 \\
(57.1 \%)\end{array}$ & $\begin{array}{l}44 \text { of } 49 \\
(89.8 \%)\end{array}$ & $\begin{array}{l}46 \text { of } 49 \\
(93.9 \%)\end{array}$ \\
\hline $\begin{array}{l}\text { Right to Act by Written } \\
\text { Consent }\end{array}$ & $38.6 \%$ & \begin{tabular}{|c|}
27 of 50 \\
$(54 \%)$
\end{tabular} & $\begin{array}{c}41 \text { of } 50 \\
(82 \%)\end{array}$ & $\begin{array}{c}43 \text { of } 50 \\
(86 \%)\end{array}$ \\
\hline \multicolumn{2}{|l|}{ Overall Other Governance } & $\begin{array}{l}68 \text { of } 217 \\
(31.3 \%)\end{array}$ & $\begin{array}{c}135 \text { of } 217 \\
(62.2 \%)\end{array}$ & $\begin{array}{c}163 \text { of } 217 \\
(75.1 \%)\end{array}$ \\
\hline
\end{tabular}

An analysis of the margins by which proxy votes are won or lost reveals that a meaningful number of shareholder proposals are sufficiently controversial so as to be within the influence of the Big Three's voting power. This means that just three stewardship teams, and frequently even just two or one stewardship teams, have the power to affect governance out-

92. Table 14 is based on data on the outcomes of shareholder proposals for the largest 250 U.S. public companies, as ranked by Fortune magazine, collected by Proxy Monitor. Id. 
comes at the largest corporations in the United States. The narrow margins for many governance votes underscore the reality that index funds are already shaping corporate decision-making and are already determining the outcome of a significant portion of proxy votes.

\section{All Shareholder Proposals}

Table 15 reveals that, in all, nearly one-fifth of shareholder proposals won or lost by margins of less than $10.6 \%$, over four-tenths won or lost by margins of less than $19.6 \%$, and nearly six-tenths won or lost by margins of less than $25 \%$. Governance proposals had the narrowest margins, while social and environmental proposals had slightly wider margins.

Table 15: Voting Margins on All Shareholder Proposals ${ }^{93}$

This Table provides data on the proportion of shareholder proposals that fell within margins of 10.6\% (Big One), 19.6\% (Big Two), and 25\% (Big Three) in calendar years 2018 and 2019.

\begin{tabular}{|c|c|c|c|}
\hline Category & Big One & Big Two & Big Three \\
\hline Environmental & $\begin{array}{c}9 \text { of } 57 \\
(15.8 \%)\end{array}$ & $\begin{array}{c}20 \text { of } 57 \\
(35.1 \%)\end{array}$ & $\begin{array}{c}28 \text { of } 57 \\
(49.1 \%)\end{array}$ \\
\hline Social & $\begin{array}{c}19 \text { of } 155 \\
(12.3 \%)\end{array}$ & $\begin{array}{c}53 \text { of } 155 \\
(34.2 \%)\end{array}$ & $\begin{array}{c}76 \text { of } 155 \\
(49.0 \%)\end{array}$ \\
\hline Governance & $\begin{array}{c}72 \text { of } 299 \\
(24.1 \%)\end{array}$ & $\begin{array}{c}151 \text { of } 299 \\
(50.5 \%)\end{array}$ & $\begin{array}{c}195 \text { of } 299 \\
(65.2 \%)\end{array}$ \\
\hline All Shareholder Proposals & $\begin{array}{c}100 \text { of } 511 \\
(19.6 \%)\end{array}$ & $\begin{array}{c}224 \text { of } 511 \\
(43.8 \%)\end{array}$ & $\begin{array}{c}299 \text { of } 511 \\
(58.5 \%)\end{array}$ \\
\hline
\end{tabular}

Overall, these findings reveal that a significant proportion of shareholder proposals have relatively thin margins relative to the voting power of the Big Three. Thus, the Big Three may already be in a position to determine the outcome of the majority of shareholder proposals. In this way, the risks associated with concentrating voting power in the hands of a few stewardship teams is not just a future possibility but a present reality.

\section{IMPLICATIONS}

The data in Part III reveal that the Big Three index funds possess significant voting power at America's largest companies today, not just at some point in the future. The data in Part IV demonstrate that margins are close enough on controversial topics to permit the Big Three, or even the Big Two or the Big One, to determine the outcome of numerous proxy votes right now, not just in a decade or two. Together, the data

93. Table 15 is based on data on the outcomes of shareholder proposals for the largest 250 U.S. public companies, as ranked by Fortune magazine, collected by Proxy Monitor. Id. 
confirm that the Big Three have already radically transformed the corporate governance arena. While only two decades ago, it was possible to overlook the Big Three's voting activities as inconsequential, their voting activities are now commonly outcome determinative and thus demand careful scrutiny.

Fiduciary duties obligate index funds to vote shares "in a manner consistent with the best interests" of index fund investors. ${ }^{94}$ In assessing whether and to what extent index funds are using their considerable, often decisive, power in the "best interests" of their investors, two questions are paramount: First, what are those best interests? Second, who is in the best position to decide?

As to the latter question, the Big Three have made it abundantly clear through their actions (and inaction) that they believe their own employees are fit to unilaterally decide the "best interests" of investors without any meaningful input from those investors and without any attempt to discern those investors' actual preferences and interests. ${ }^{95}$ To the extent that the Big Three's priorities differ from those of their investors, this paternalism frustrates the purpose of the best interests standard and the spirit of their fiduciary obligations.

As to the former question, the Big Three's voting behaviors speak for themselves and often in ways that are very likely to conflict with the views and values of their alleged principals, at least to the extent the index fund populace mirrors the American public at large. For example, in the environmental realm, the Big Three rarely support environmental proposals ${ }^{96}$ despite the fact that $74 \%$ of Americans say that "the country should do whatever it takes to protect the environment." 97 Likewise, $68 \%$ of Americans believe that the government is doing too little to protect water quality, and $67 \%$ of Americans believe that the government is doing too little to protect air quality. ${ }^{98}$ However, the Big Three very rarely supported shareholder proposals seeking to address pollution. ${ }^{99}$

Similar discrepancies can be seen on social topics. Even though $73 \%$ of Americans believe that companies should do more to promote gender

94. Disclosure of Proxy Voting, supra note 2, at 6565.

95. See generally Caleb N. Griffin, We Three Kings: Disintermediating Voting at the Index Fund Giants, MD. L. REv. (forthcoming 2020) (manuscript at 9-14) (available at https://ssrn.com/abstract_id=3365222).

96. Griffin, supra note 62, at 24-25.

97. Monica Anderson, For Earth Day, Here's How Americans View Environmental Issues, Pew Res. Ctr. (Apr. 20, 2017), https://www.pewresearch.org/fact-tank/2017/04/20/ for-earth-day-heres-how-americans-view-environmental-issues/ [https://perma.cc/XXP8PKT4].

98. Majorities of Americans Say the Federal Government is Not Doing Enough to Protect the Climate, Environment, PEw REs. CTR. (Feb. 27, 2020), https://www.pewresearch.org/fact-tank/2020/02/28/more-americans-see-climate-change-as-a-priority-butdemocrats-are-much-more-concerned-than-republicans/ft_2020-02-28_climatechange_03/ [https://perma.cc/VDV3-UYZE].

99. Griffin, supra note 62 , at 24. 
pay equity, 100 the Big Three rarely $(9.6 \%$ of the time for BlackRock and $24 \%$ of the time for State Street) or never (for Vanguard) support proposals seeking to address the gender pay gap. ${ }^{101}$ In a similar vein, the Big Three very rarely support proposals to promote increased transparency of corporate lobbying activities, ${ }^{102}$ even though $59 \%$ of Americans believe that corporate lobbyists have too much power. ${ }^{103}$ From 2018-2019, none of the Big Three supported even one shareholder proposal related to data privacy, ${ }^{104}$ even though $81 \%$ of Americans believe that the risks of companies collecting their data outweigh the benefits and $79 \%$ of Americans are very or somewhat concerned about data privacy. ${ }^{105}$

The discrepancies between likely investor preferences and actual voting behaviors persist despite the existence of simple, legal, inexpensive, and efficient methods of increasing the alignment between the two. The first method is pass-through voting instructions. This mechanism has two distinct features: (i) "pass through voting" and (ii) "instructions" for proxy voting. Part (i), pass-through voting, involves viewing the index fund for what it really is: a conduit for investing in company stock. When so viewed, it makes little sense to vest proxy voting rights in the conduit rather than in the actual investors. Rather, under this reform, proxy voting rights would "pass through" the index fund intermediary to the actual investor. Pass-through voting would help to mitigate the problem of concentrated index fund power by transferring this power from index funds to their investors. Further, this reform would increase the accountability of index fund agents and promote alignment between proxy voting outcomes and investor preferences. Instead of utilizing their own judgment on proxy votes, index fund stewardship teams would be constrained by index fund investors' actual, directly expressed preferences.

Part (ii), allowing investors to issue "instructions" on how their investments should be voted, is designed to simplify the voting process and reduce the burden of the overwhelming number of votes index fund investors would otherwise need to consider. These instructions use a simple "If X, do Y" format, allowing investors to utilize voting guidelines in a similar fashion as index fund stewardship teams. For instance, an investor could say "Vote yes on all proposals to disclose carbon emissions," or

100. Jillesa Gebhardt, On Equal Pay Day 2019, Lack of Awareness Persists, SuRveYMonkey (Apr. 2, 2019), https://www.surveymonkey.com/curiosity/equal-pay-day2019/ [https://perma.cc/TTB6-KGD5].

101. Griffin, supra note 62, at 18.

102. Id. at 69 .

103. Neil Irwin, Americans Are O.K. With Big Business. It's Business Lobbying Power They Hate., N.Y. Times (Sept. 23, 2014), https://www.nytimes.com/2014/09/24/upshot/americans-are-ok-with-big-business-its-business-lobbying-power-they-hate.html [https:// perma.cc/D49Z-X3ZK].

104. Griffin, supra note 62, at 21.

105. Brooke Auxier et al., Americans and Privacy: Concerned, Confused and Feeling Lack of Control Over Their Personal Information, PEw Res. CTR. (Nov. 15, 2019), https:// www.pewresearch.org/internet/2019/11/15/americans-and-privacy-concerned-confusedand-feeling-lack-of-control-over-their-personal-information/ [https://perma.cc/M3DW39JD]. 
"Vote yes on all proposals to disclose political spending," and the fund would vote the investor's shares that way at each company where the issue arose. This is essentially how index funds themselves deal with the overwhelming number of votes they must cast-via generalized voting guidelines that they apply to similar issues across hundreds of companies. ${ }^{106}$ If index funds or regulators so choose, it could be investors, rather than a handful of top index fund employees, setting the voting guidelines themselves. Additionally, requiring index funds to follow investor-generated guidelines necessarily requires index funds to vote their proxies proportionately rather than as an undifferentiated bloc. By splitting the votes of the Big Three index funds and removing some of their discretionary voting power, this proposal would substantially reduce their concentrated proxy voting influence.

Combining the two subproposals, pass-through voting instructions would allow investors, rather than stewardship teams, to decide how they would like to vote on important issues, such as climate change, political spending, and board diversity, and then require index funds to carry out investors' voting instructions until otherwise informed. Because investorgenerated voting instructions could be highly variable, regulators should propose a limited menu of standardized voting instructions to eliminate the need for complex, individualized interpretation. In crafting such a standardized menu, regulators should balance the positive aspects of investor voice and limiting discretionary voting by index fund agents against the potential costs produced by allowing overly idiosyncratic voting instructions. Ultimately, when compared to the hundreds of thousands of case-by-case determinations called for with simple passthrough voting of index funds, pass-through voting instructions would substantially economize voting effort and drastically simplify the proxy voting process for investors by allowing them to make decisions in an issue-based manner.

The second method of increasing investor involvement, "proxy choice," recognizes that, even when voting is drastically simplified and voting effort is economized, not all investors will desire to vote on all issues. Moreover, some issues may simply be too complex for standardized voting guidelines and will instead require case-by-case analysis. Thus, the second proposal suggests that investors should be able to choose who is voting on their behalf. For example, if an individual were invested in a fund at Vanguard but wanted his or her shares voted to mirror State Street's, the investor could tell Vanguard to do so. Likewise, if an investor identified a proxy advisory firm or asset manager that better mirrored her investment priorities or values, she would be able to have her shares voted according to that entities' voting recommendations. "Proxy choice" would unify the financial and voting dimensions of index investing by allowing investors to control both investment decisions (i.e., in which basket of stocks to

106. See Lund, supra note 11 , at 516 (describing the use of generic voting guidelines at index funds to streamline voting decisions). 
invest) and stewardship decisions (i.e., how to vote those stocks) - just as those who directly invest in stock choose both in which stocks they want to invest and how to vote those stocks. Proxy choice would thus permit investors greater discretion in the proxy voting arena because investors would have the ability to broadly direct how their investments were voted, and it would increase accountability for voting behaviors because investors would have a mechanism to reject inferior voting and select superior voting.

A third method of increasing investor involvement would involve the Big Three index funds and their competitors seeking out greater information about investor preferences, values, and financial interests via a survey or poll. Index funds can relatively cheaply and easily identify their investors' preferences on the most salient topics at issue in proxy contests, engagements, and priority-setting efforts simply by asking those investors for their input. For example, index funds could give investors the option to state a preference for whether corporations should be required to establish greenhouse gas emissions targets or to express their opinion on whether firms should make disclosures related to gender pay equity. Similarly, funds could seek out information about investors' risk tolerances and timelines for investment, which could help them make decisions on key governance topics. Funds could voluntarily use this information to ensure that voting behaviors do indeed reflect investors' interests, or, alternatively, regulators could require that funds do so.

The overall intuition for these three proposals is that the law's current decoupling of economic ownership from voting power is a historical accident, and this historical accident is the fundamental problem driving most other index fund issues. Each of these proposals is premised on the assumption that ownership and voting power should go together to the greatest extent possible. Given the focus on agency costs-problems created by the separation of ownership and control-that animates so much of corporate legal scholarship, this assumption should be relatively uncontroversial. It is incumbent upon regulators to require mechanisms such as the three outlined above that could hold index funds accountable for accurately reflecting investors' best interests in their proxy votes, given the great power already in the hands of index funds. Such a move would have the additional positive effects of reducing the concentrated power in the hands of index funds, providing a necessary check on stewardship teams' voting dominance, diversifying the pool of corporate governance decisionmakers, and restoring the promise of shareholder democracy.

\section{CONCLUSION}

The data presented in this Article reveal that the Big Three already have substantial power to determine the fate of controversial shareholder proposals. A considerable portion of proposals are likely won or lost based upon the Big Three's support or lack thereof. In many cases, just 
one or two index funds alone may have the power to determine voting outcomes. As a byproduct of simple mathematics, the Big Three's collective and individual power is greatest on the most controversial ballot items-i.e., where voting margins are the narrowest. Thus, the Big Three's support is likely to be outcome determinative on precisely those issues that are most hotly contested.

The Big Three wield this power in ways unlikely to correspond to their investors' preferences, values, and interests. ${ }^{107}$ Their voting decisions are not based upon any meaningful input from those investors, but upon the opinions of stewardship teams comprised of index fund employees. The lack of deference to-or even awareness of-investor preferences was perhaps excusable when index funds had only a very limited ability to influence proxy voting outcomes. However, as this Article demonstrates, index funds are already playing a pivotal role in corporate governance at America's largest companies. It is therefore crucial for index funds' power to be tethered to the actual preferences of their investors.

107. See Griffin, supra note 95 (manuscript at 13). 
